\title{
Neuropilin-1 is a glial cell line-derived neurotrophic factor receptor in glioblastoma
}

\section{ABSTRACT}

The aim of this study was to identify the receptor for glial cell line-derived neurotrophic factor (GDNF) in glioblastoma multiforme (GBM). After GST pull-down assays, membrane proteins purified from $\mathrm{C} 6$ rat glioma cells were subjected to liquid chromatography-tandem mass spectrometry (LC-MS/MS). The differentially expressed proteins were annotated using Gene Ontology, and neuropilin-1 (NRP1) was identified as the putative GDNF receptor in glioma. NRP1 was more highly expressed in human GBM brains and $C 6$ rat glioma cells than in normal human brains or primary rat astrocytes. Immunofluorescence staining showed that NRP1 was recruited to the membrane by GDNF, and NRP1 co-immunoprecipitated with GDNF. Using the NRP1 and GDNF protein structures to assess molecular docking in the ZDOCK server and visualization with the PyMOL Molecular Graphics System revealed 8 H-bonds and stable positive and negative electrostatic interactions between NRP1 and GDNF. RNAi knockdown of NRP1 reduced proliferation of $\mathrm{C6}$ glioma cells when stimulated with GDNF. NRP1 was an independent risk factor for both survival and recurrence in GBM patients. High NRP1 mRNA expression correlated with shorter OS and DFS (OS: $\chi^{2}=4.6720, P=0.0307$; DFS: $\left.\chi^{2}=11.013, P=0.0009\right)$. NRP1 is thus a GDNF receptor in glioma cells and a potential therapeutic target.

\section{INTRODUCTION}

Glioblastoma (GBM) is one of the most common primary tumors of the central nervous system (CNS) with poor survival outcomes. It is characterized by uncontrolled cellular proliferation that is driven by a complex integration of a various extracellular stimuli that signal through multiple membrane receptor systems, resulting in elaborate changes in gene expression [1]. Therefore, agents that block one or more aberrant signaling pathways 
that promote tumor growth and proliferation can potentially reduce the severe mortality and morbidity in GBM patients [2].

Glial cell line-derived neurotrophic factor (GDNF), a member of the GDNF family of ligands (GFL), is strongly expressed in human gliomas [3]. Knock-down of GDNF and its binding receptor, GDNF family receptor alpha 1 (GFRA1) decreases the proliferation of C6 glioma cells [4]. However, the mechanisms downstream of GDNF binding to $\mathrm{C} 6$ cells are not clear because of multiple signal transducing receptors for GDNF in different cells.

Since extracellular signaling molecules modulate cellular functions by binding to specific transmembrane receptor proteins [5], it is important to identify the GDNF receptors on glioma cells. GDNF transmits signals through a multi-component receptor system that consists of glycosylphosphatidyl inositol (GPI)-linked GFRA1 [6] and proto-oncogene tyrosine-protein kinase receptor RET [7]. Formation of the $\mathrm{GDNF}_{2}-\mathrm{GFRA}_{2}-\mathrm{RET}_{2}$ heterohexameric complex results in transphosphorylation of RET, thereby activating the receptor tyrosine kinase signaling pathway [8-10]. However, binding of GDNF to the neural cell adhesion molecule, NCAM, instead of RET results in activation of Fyn, which regulates Schwann cell migration and axonal growth in hippocampal neurons [11]. In 2011, Bespalov et al reported that heparan sulfate proteoglycan, syndecan-3 (SDC3) was a novel receptor for GDNF, which either directly transmitted the GFL signals or acted as a co-receptor and presented GFLs to RET [12]. In many cases, ligands have multiple receptors, which can induce different responses in the same or different cell types [5]. Therefore, in view of the unique biological features of GBM, it is possible that hypersecretion of GDNF in combination with its signaling through multiple receptors plays a role in promoting GBM cell growth and proliferation [3].

In recent years, proteomics has helped identify novel protein-protein interactions (PPIs) [13]. Therefore, in this study, we used a combination of GST pull-down assays with mass spectrometry (MS) and bioinformatic methods to identify the membrane receptor for GDNF on rat C6 glioma cells.

\section{RESULTS}

\section{GDNF promotes the proliferation of $\mathbf{C} 6$ glioma cells}

Serum starvation of C6 glioma cells resulted in $80 \%$ $\mathrm{G} 0 / \mathrm{G} 1$ phase cells compared to $63.3 \%$ in $\mathrm{C} 6$ cells grown with $10 \%$ FBS $(P<0.05)$. CCK-8 assay demonstrated that $40 \mathrm{ng} / \mathrm{ml}$ was the most optimal concentration of GDNF and the $48 \mathrm{~h}$ time point showed peak $\mathrm{C} 6$ cell viability $(* * * P<0.001)$. These data were further confirmed by flow cytometry and EdU assays $(* * P<0.01)$.

\section{NRP1 is the putative GDNF-receptor in glioma cells}

Membrane fractions were purified from rat C6 cells and primary astrocytes (ASTs) and separated on SDSPAGE with nuclear fraction and total cellular protein and stained with Coomassie brilliant blue. Comparatively fewer membrane proteins were observed compared to total and nuclear fraction (Figure 1A). Western blot analysis showed that $\mathrm{Na} / \mathrm{K}$ ATPase was present only in the membrane fraction and absent in the nuclear fraction demonstrating purity of the membrane protein preparation (Figure 1B).

The membrane protein fractions from $\mathrm{C} 6$ rat glioma cells (C6) and primary rat astrocytes (AST) were then used for GST pull-down assay with GST or GSTGDNF fusion proteins and silver staining was performed after running the samples on SDS-PAGE (Figure 2). To identify the membrane proteins that bind to GDNF, liquid chromatography-tandem mass spectrometry (LCMS/MS) results. More number of proteins and peptides were identified in the C6-GDNF-GST and AST-GDNFGST groups than control GST alone groups (Table 1). Label-free quantitative (LFQ) method demonstrated that the distribution of protein abundance in all 4 groups was normal and there was higher correlation of protein abundance among the same group (data not shown).

The differentially expressed proteins (DEPs) identified by MS in the 4 groups were analyzed by bioinformatics. The strategy involved analyzing (1) membrane proteins that were bound to GDNF in the pull down assay; (2) those that were found in both C6-GDNFGST and AST-GDNF-GST groups and; (3) those that demonstrated higher binding capacity in C6 compared to AST groups.

The DEPs were annotated with Gene Ontology (GO) terms using PANTHER Classification System with the search parameter 'membrane receptor' [14]. We selected and combined (1) receptor activity (GO:0004872) and receptor binding (GO:0005102) for molecular function (MF); (2) biological adhesion (GO:0022610) and growth (GO:0040007) for biological process (BP); (3) extracellular matrix (GO:0031012), extracellular region (GO:0005576), integral to membrane (GO:0016021) and plasma membrane (GO:0005886) for cellular component (CC); and (4) cell adhesion molecule (PC00069), extracellular matrix protein (PC00102), membrane traffic protein (PC00150), receptor (PC00197) and transmembrane receptor regulatory/adaptor protein (PC00226) for protein Class (PC). Based on this analysis, we identified Attractin (ATRN), neuropilin-2 (NRP2) and NRP1 as common proteins (data not shown).

Analysis of human GBM and normal brain data from TCGA datasets revealed that mRNA levels of GFRA1, RET, NCAM1, CDH2, SDC3 and ATRN were 


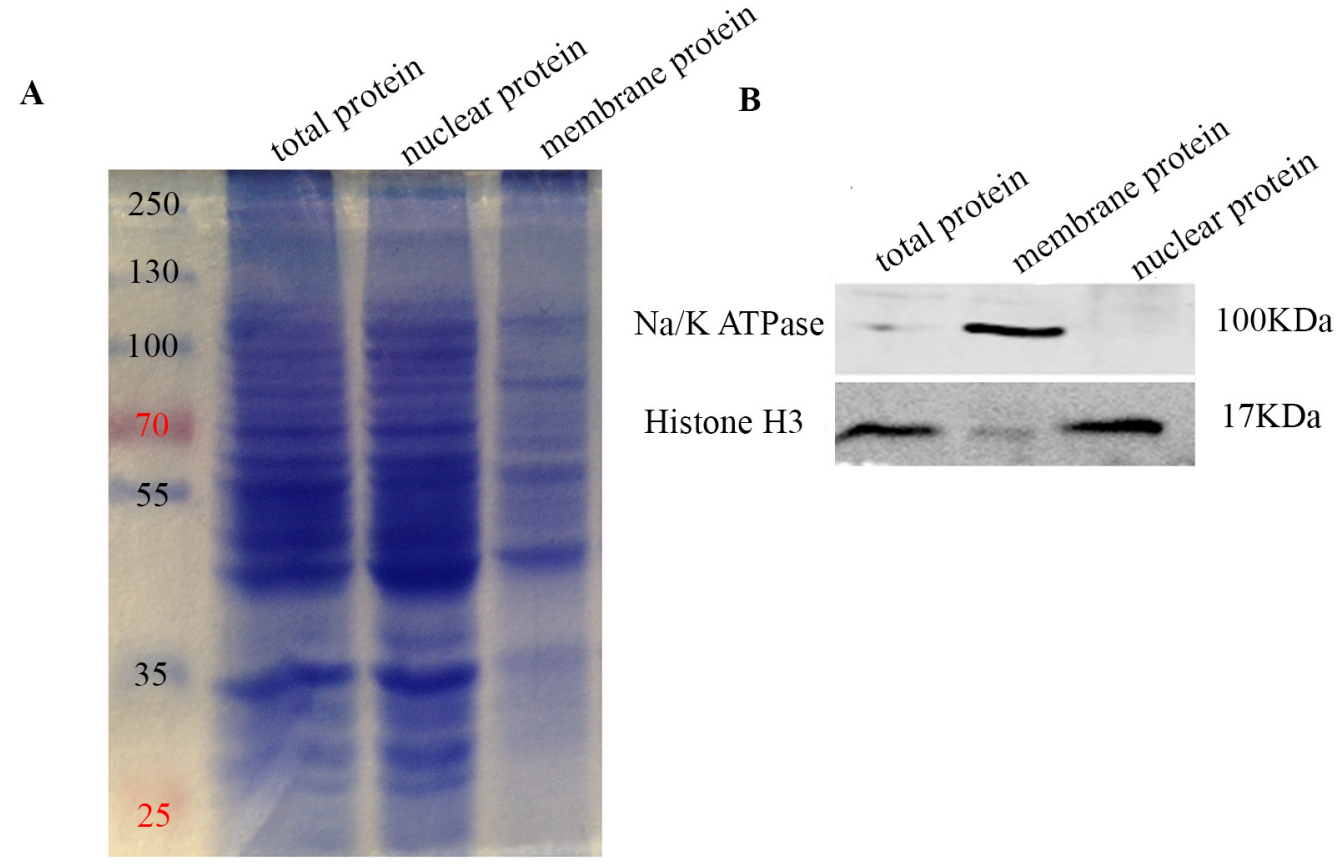

Figure 1: Western blot analysis of membrane proteins purification. (A) Coomassie Brilliant Blue stained SDS-PAGE gel showing molecular weight marker (lane1), total C6 cellular protein (lane2), nuclear protein fraction (lane3) and purified membrane protein fraction (lane4). $30 \mu \mathrm{g}$ protein was loaded in lanes 2-4. As shown, membrane fraction has fewer number of proteins compared to the nuclear fraction and total cellular protein. Molecular weight marker shows 250, 130, 100, 70, 55, 35, and 25kDa bands. (B) Western-blot analysis shows $\mathrm{Na}^{+} / \mathrm{K}^{+}$ATPase (100 kDa membrane protein) and histone $\mathrm{H} 3$ (17 kDa nuclear protein) in total C6 cellular protein (lane1), nuclear protein fraction (lane2) and purified membrane protein fraction (lane3). As shown, $\mathrm{Na}^{+} / \mathrm{K}^{+}$ATPase is enriched in the membrane fraction, whereas histone $\mathrm{H} 3$ is enriched in the nuclear fraction.
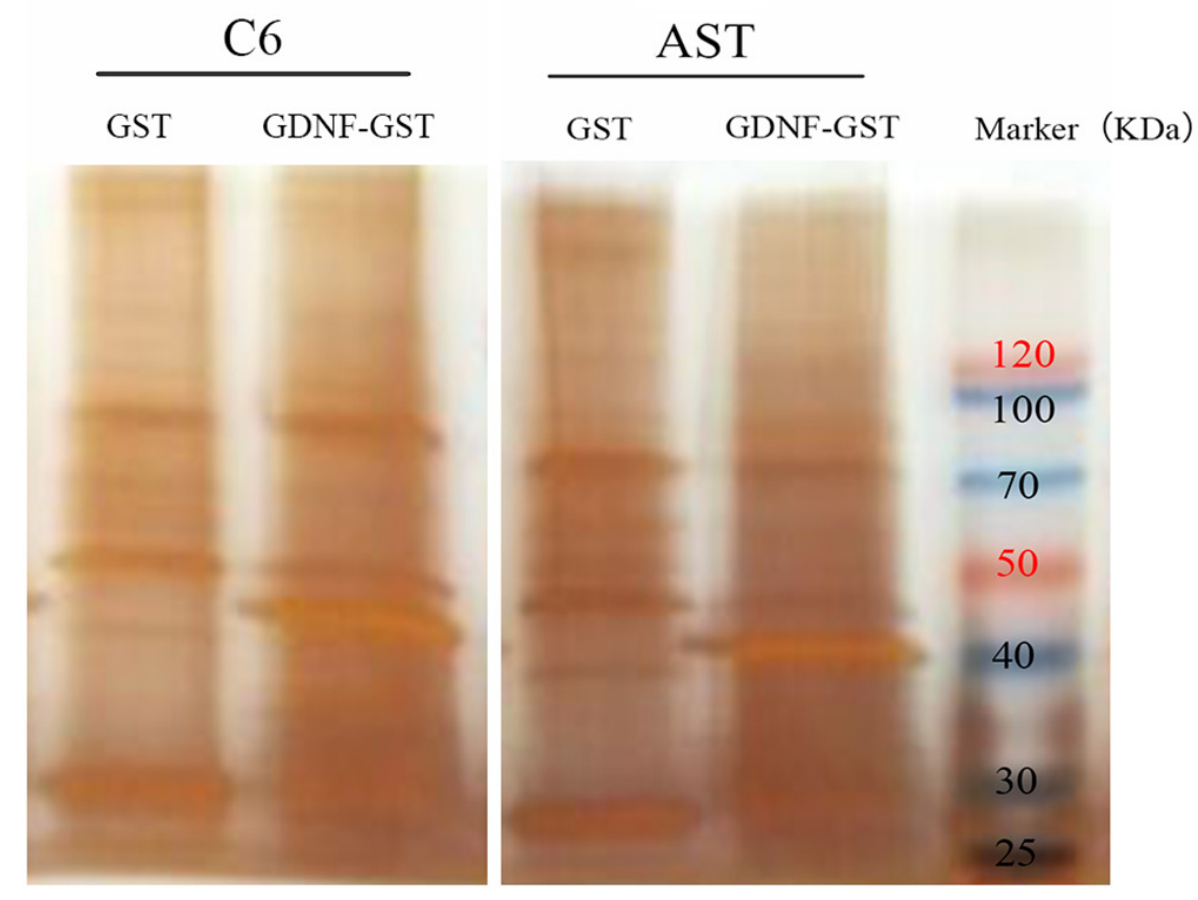

Figure 2: GST pull-down assay to identify membrane proteins binding to GDNF. Silver stained SDS-PAGE gel shows membrane proteins from C6 rat glioma cells (C6) and primary rat astrocytes (AST) pulled down by either GST or GDNF-GST fusion protein. Lane1, C6-GST; Lane2, C6-GDNF-GST; Lane3, AST-GST; Lane 4, AST-GDNF-GST; Lane 5, protein molecular weight marker. Note: GST: GST alone; GDNF-GST: GDNF-GST fusion protein. 
Table 1: Summary of LC-MS/MS analysis

\begin{tabular}{lcccc}
\hline Samples & $\begin{array}{c}\text { Total_number of } \\
\text { spectra }\end{array}$ & $\begin{array}{c}\text { Total number of } \\
\text { identified_spectra }\end{array}$ & $\begin{array}{c}\text { Total number of } \\
\text { identified_peptides }\end{array}$ & $\begin{array}{c}\text { Total number of } \\
\text { identified_proteins }\end{array}$ \\
\hline C6 GDNF-GST & 49558 & 6445 & 4527 & 1652 \\
C6 GST & 48122 & 4770 & 3043 & 1231 \\
AST GDNF-GST & 48548 & 6934 & 4407 & 1537 \\
AST GST & 46530 & 4522 & 2978 & 1134 \\
\hline
\end{tabular}

C6: C6 rat glioma cells; AST: primary rat astrocytes; GDNF-GST: fusion of GDNF and GST proteins; GST: GST protein alone.

comparable $(p>0.05)$, whereas mRNA levels of Integrin beta-1 (ITGB1), NRP1 and NRP2 were elevated in the GBM brains $(P<0.01, \mathrm{FC}>1.5$; Figure 3$)$.

\section{NRP1 is overexpressed in glioma cells and recruited to the membrane by GDNF}

NRP1 was in the top $1 \%$ among the highly expressed mRNAs in the GBM brains compared to normal brains from the TGCA dataset (Figure 3; $P$-value $=7.03 \mathrm{E}^{-15}$, $\mathrm{t}$-Test $=16.370$, Fold Change $=2.205$ ). Immunofluorescence staining also demonstrated high NRP1 expression in C6 glioma cells compared to normal astrocytes (Figure 4; $\mathrm{p}<0.05$ ). Further, immunofluorescent (IF) staining showed that exogenous GDNF recruited more NRP1 to the cell membrane of $\mathrm{C} 6$ glioma cells, whereas the non-GDNF treated cells showed diffused cytoplasmic staining for NRP1 (Figure 5).

\section{Structural and functional analysis of NRP1 interaction with GDNF}

The molecular docking between GDNF and NRP1 was performed with ZDOCK software and the molecular conformations with top 10 docking scores were selected (data not shown). Visual analysis by PyMOL software on the molecular conformation with the highest score (11201.180) showed formation of 8 hydrogen bonds (H-bonds) between GDNF and NRP1 (Figure 6A-6D and Table 2). Among them, aa at 201 (ARG) of GDNF formed 4 H-bonds with aa residues 428 (ASP) and 274 (LYS) of NRP1. Stable positive and negative electrostatic interactions were also demonstrated between NRP1 and GDNF by the Adaptive Poisson-Boltzmann Solver (APBS) plug-in of PyMOL software (Figure 6E and $6 \mathrm{~F})$. These data demonstrated the molecular interaction between NRP1 and GDNF on the surface of C6 glioma cells.

To confirm the interaction between GDNF and NRP1, C6 cells were treated with or without exogenous GDNF and co-imunoprecipitated with either IgG (control group), anti-NRP1 (NRP1 group) or anti-GDNF (GDNF group). Western blot analysis showed that NRP1 was co-immunoprecipitated with GDNF in both groups; stoichiometric ratios of NRP1 and GDNF in both groups were very different (Figure 7).

\section{GDNF-NRP1 interaction promotes proliferation of C6 glioma cells}

Next, to ascertain if GDNF promoted proliferation of C6 glioma cells through NRP1, we performed knockdown of rat NRP1 using the lentivector shRNA transduction of C6 glioma cells. CCK8 proliferation assay showed that NRP1 RNAi resulted in decreasing proliferation of $\mathrm{C} 6$ glioma cells treated with exogenous GDNF compared to $\mathrm{C} 6$ cells transduced with CON77 RNAi (Figure $8 ; P<0.05$ ). This suggested that NRP1 interaction with exogenous GDNF promoted proliferation of C6 glioma cells.

\section{NRP1 expression correlates with GBM prognosis}

Treatment of C6 glioma cells with exogenous GDNF resulted in increased expression of NRP1 protein and mRNA (Figure 9). To decipher the clinical significance of this finding, the association of overall survival (OS) and disease-free survival (DFS) was analyzed with NRP1 mRNA levels in the TCGA GBM dataset. GBM patients with high NRP1 mRNA expression demonstrated shorter OS and DFS than patients with low or normal NRP1 mRNA levels (OS: $\chi^{2}=4.6720, P=0.0307$, Table 3; DFS: $\chi^{2}=11.013, P=0.0009$, Table 4).

Multivariate proportional hazard model analysis demonstrated that high NRP1 mRNA expression was correlated with OS (Log likelihood $=-527.61204$, $\left.\chi^{2}=22.33, P=0.0001\right)$ and DFS (Log likelihood $=-322.120$, $\left.\chi^{2}=15.760, P=0.0239\right)$. When compared with age and gender, high NRP1 mRNA levels were an independent risk factor, reducing the survival time of patients and enhancing the risk of death by 2.5866 times compared to the control group (Table 5). The high NRP1 mRNA levels were also an independent risk factor for the recurrence of patients, with the risk of recurrence in the high NRP1 expression group being 3.6364 times higher than the control group (Table 6). Kaplan-Meier survival analysis 

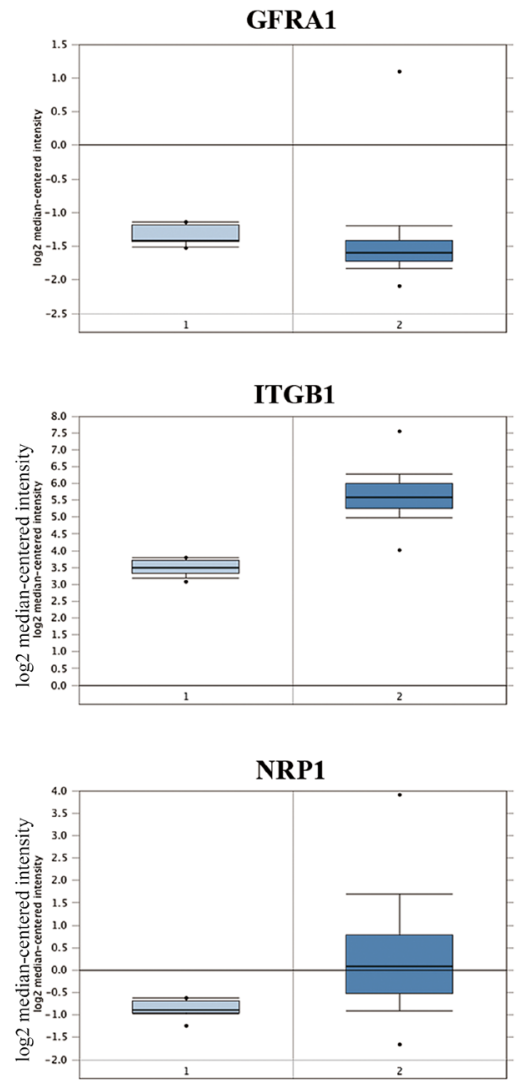
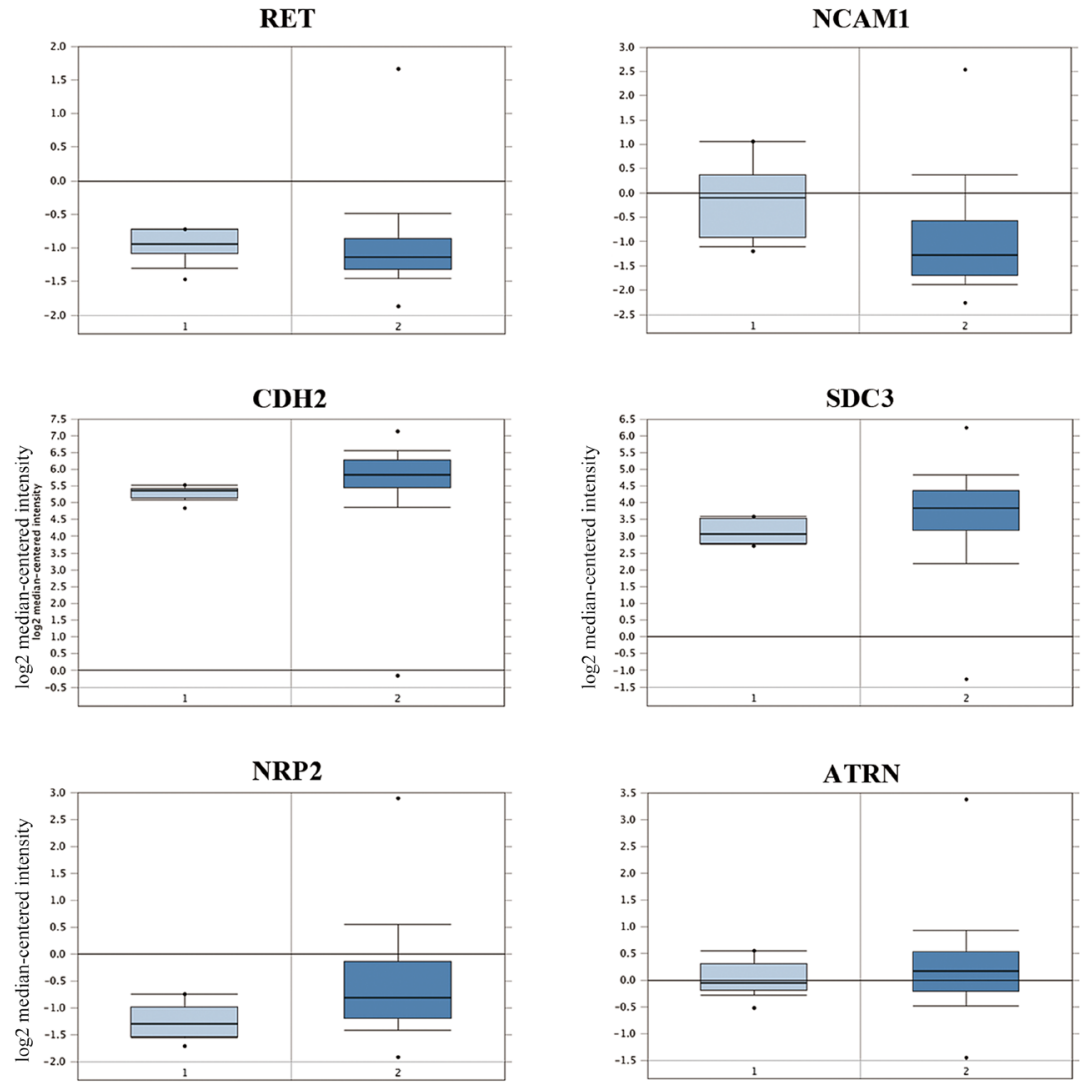

Figure 3: Analysis of candidate membrane receptors for GDNF in human glioblastoma patient samples. Comparison of mRNA levels (log2 median-centered intensity) of human GFRA1, RET, NCAM1, ITGB1, CDH2, SDC3, NRP1, NRP2 and ATRN in (1) normal brain samples (total 10 samples) and (2) glioblastoma brain samples (542 samples) from TCGA Brain dataset analyzed by Oncomine ${ }^{\circledR}$ Platform. Results showed that mRNA levels of GFRA1, RET, NCAM1, CDH2, SDC3 and ATRN in glioblastoma brain samples were similar to the normal brain group $(\mathrm{P}>0.05)$. On the other hand, mRNA levels of NRP1, NRP2 and ITGB1 were significantly higher in the glioblastoma brain samples compared to the normal brains $(P<0.001$ for NRP1; $P<0.01$ for NRP2 and ITGB1).

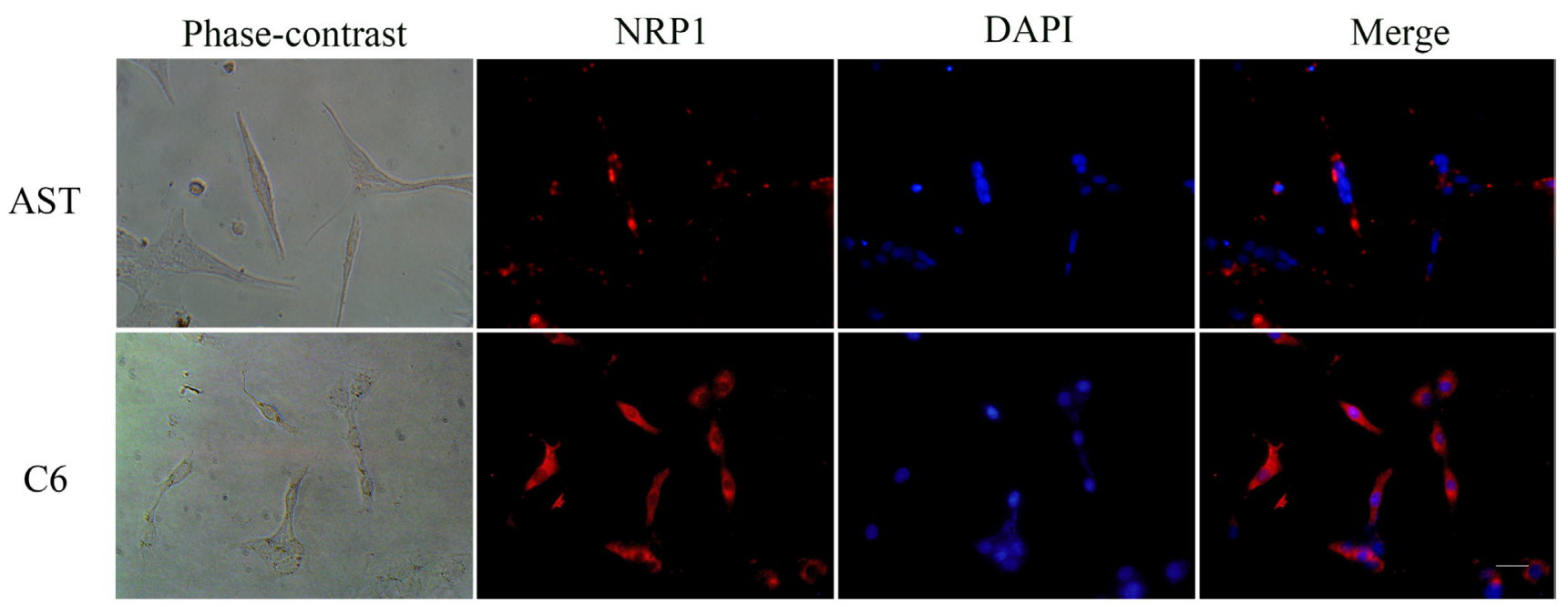

Figure 4: Immunofluorescence staining of NRP1 in C6 rat glioma cells and primary rat astrocytes. Representative immunofluorescence staining images of C6 rat glioma cells (C6) and rat primary astrocytes (AST). (Left to right) Phase contrast, NRP1 staining (probed with anti-NRP1 antibody; red), nuclear staining (DAPI; blue) and Merged (NRP1 and DAPI) images are shown for AST (top) and C6 (bottom) cells. NRP1 expression was significantly higher in C6 cells than AST $(\mathrm{P}<0.05)$. Note: scale bar $=40 \mu \mathrm{m}$. 
demonstrated that higher NRP1 mRNA correlated with shorter OS and DFS (Figure 10A and 10B).

\section{DISCUSSION}

In this study we demonstrated that NRP1 was the binding receptor in GBM cells with therapeutic potential. In previous studies, we had shown that transmembrane proteins such as integrin $\beta 1$ [15], NCAM [16] and N-cadherin [17] were involved in protective effects of GDNF on dopaminergic neurons (DAs). Since GDNF is secreted in high amounts by gliomas, we postulated that GDNF membrane receptors would also be highly expressed in gliomas. Therefore, we compared the expression of GFRA1, RET, NCAM1, ITGB1, CDH2 and SDC3 between GBM and normal brains in the TCGA database using the Oncomine ${ }^{\circledR}$ Platform. Among these, only ITGB1 showed high expression in GBM patient brains compared to normal brains.

Therefore, to identify the membrane receptors for GDNF in GBM, we perfomed a GST pull-down experiment in combination with LC-MS/MS and analyzed the membrane proteins binding to GDNF in C6 glioma cells and normal primary astrocytes, respectively. We found NCAM1 as the only differentially expressed protein (DEP) whereas the other known GDNF receptors including ITGB1 were not among the DEPs. GO analysis on the list of the DEPs identified by mass spectrometry using the PANTHER Classification System showed that 3 cell adhesion molecules, NRP1, NRP2 and ATRN, were putative GDNF receptors in glioma cells with roles in biological adhesion and growth. The Oncomine ${ }^{\circledR}$ Platform analysis showed that NRP1 and NRP2 mRNA expression was increased in GBM brains compared to normal brains, whereas ATRN was similar. Hence, NRP1 and NRP2 were identified as candidate special receptor of GDNF in C6 glioma cells and we chose to further investigate NRP1 in this study.

Previous studies showed that $\mathrm{R} / \mathrm{KXXR} / \mathrm{K}$ was the C-terminal sequence for NRP1-binding proteins or peptides [18], with either arginine or lysine residues at the ends as found in such $\operatorname{VEGF}_{165}[19,20]$ and LD224 [19]. The isoform 1 of GDNF, which was chosen as the "canonical" sequence had a C-terminal sequence as "RKHSAKRCGCI" from amino acids 201 to 211, similar to $\mathrm{R} / \mathrm{KXXR} / \mathrm{K}$ consensus sequence. Molecular docking experiments demonstrated that amino acid 201 (ARG) of GDNF formed $4 \mathrm{H}$-bonds with amino acids 428 (ASP) and 274 (LYS) of NRP1, consistent with the expected C-terminal sequence RKHSAKRCGC (amino acids 201210) of GDNF interacting with the extracellular domain of NRP1. Co-immunoprecipitation experiments established that NRP1 interacted with GDNF in C6 cells.

Neuropilins (NRPs) are non-tyrosine kinase transmembrane proteins with two identified homologues, NRP1 and NRP2 [21]. NRP1 and NRP2 share 47\%
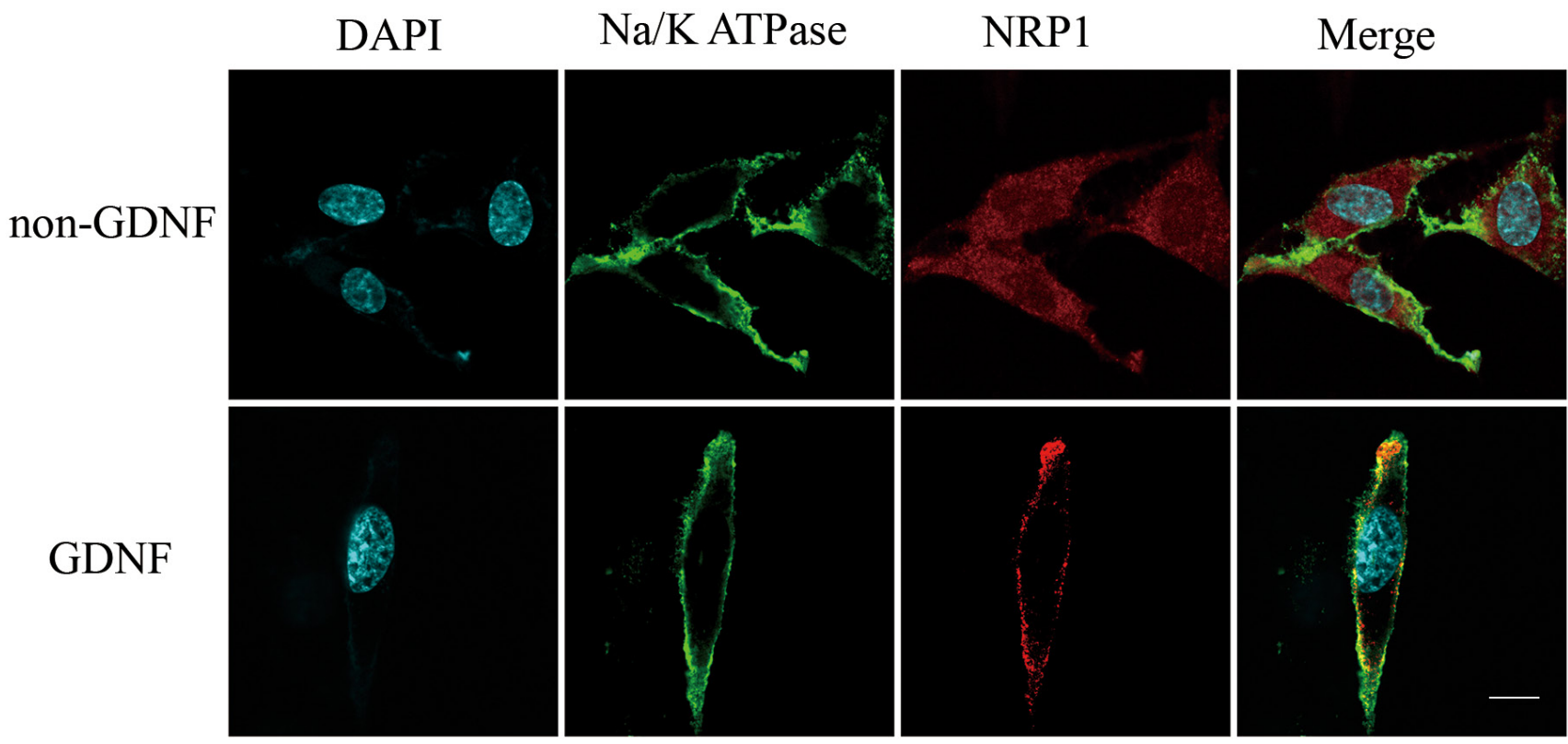

Figure 5: Immunofluorescence analysis showing membrane recruitment of NRP1 by exogenous GDNF in C6 glioma cells. Representative laser confocal immunofluorescence images of C6 rat glioma cells stained with (left to right) DAPI (blue, nuclear staining), anti-Na ${ }^{+} / \mathrm{K}^{+}$ATPase antibody (green, membrane staining), anti-NRP1 antibody (red) and merge (DAPI, anti-Na ${ }^{+} / \mathrm{K}^{+}$ATPase and anti-NRP1) in GDNF treated (bottom) and non-GDNF treated (top) cells. NRP1 was recruited to the cell membrane after short-term GDNF treatment, whereas NRP1 was localized in the cytoplasm in the non-GDNF group. Note: scale bar $=20 \mu \mathrm{m}$. 
A

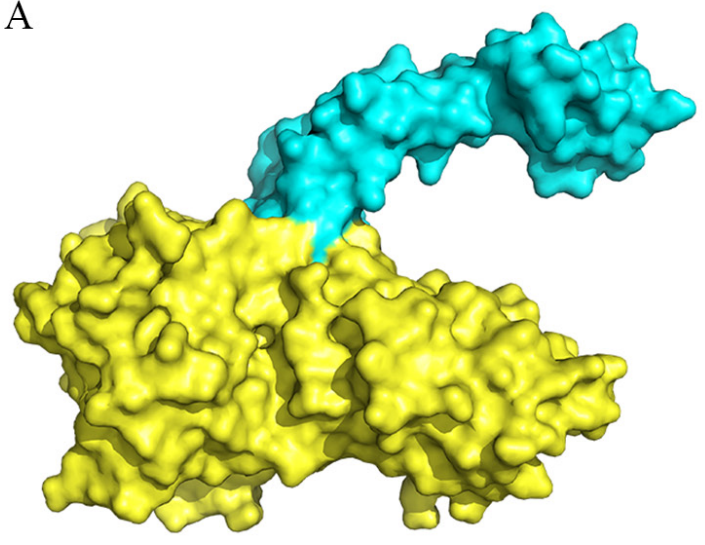

$\mathrm{C}$

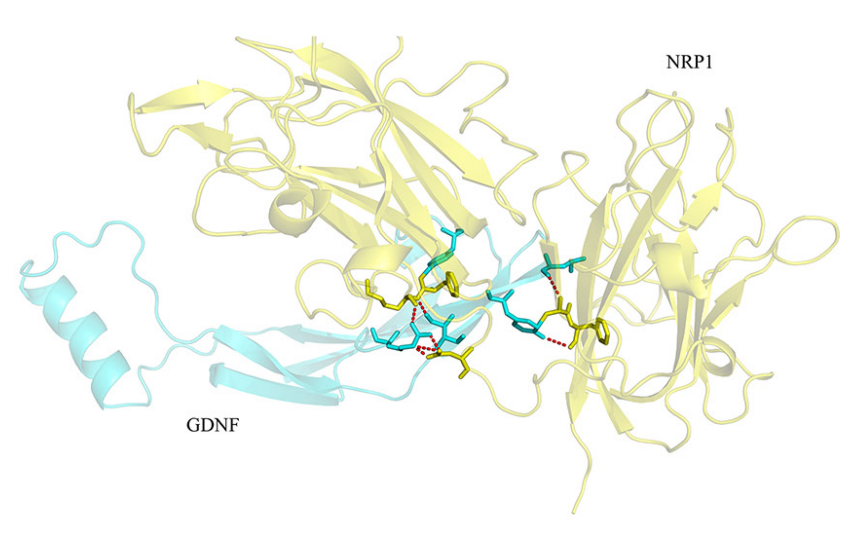

E

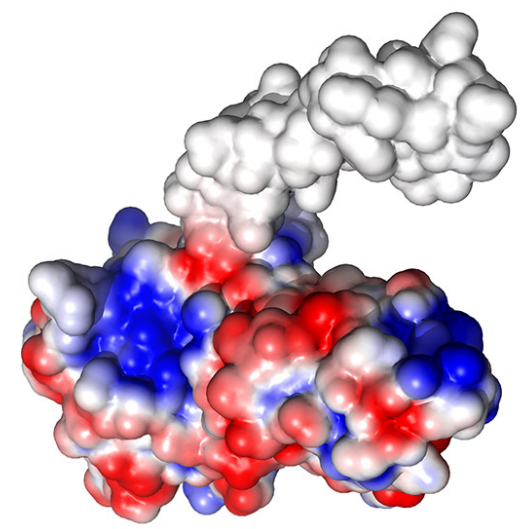

$-2.000$
B
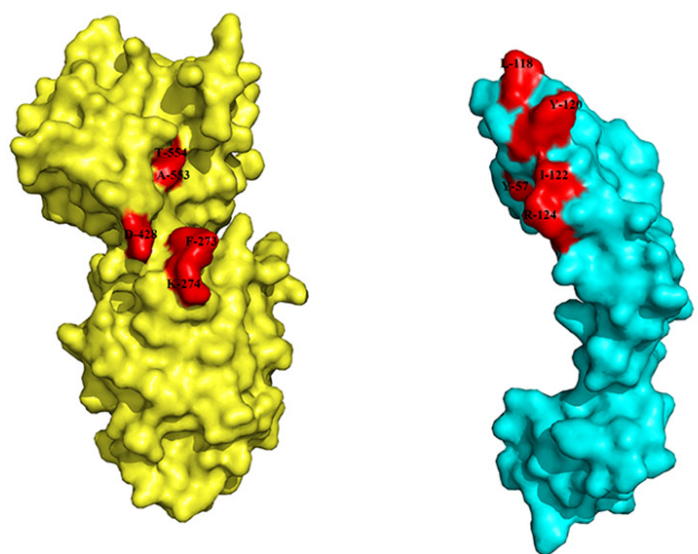

$\mathrm{D}$

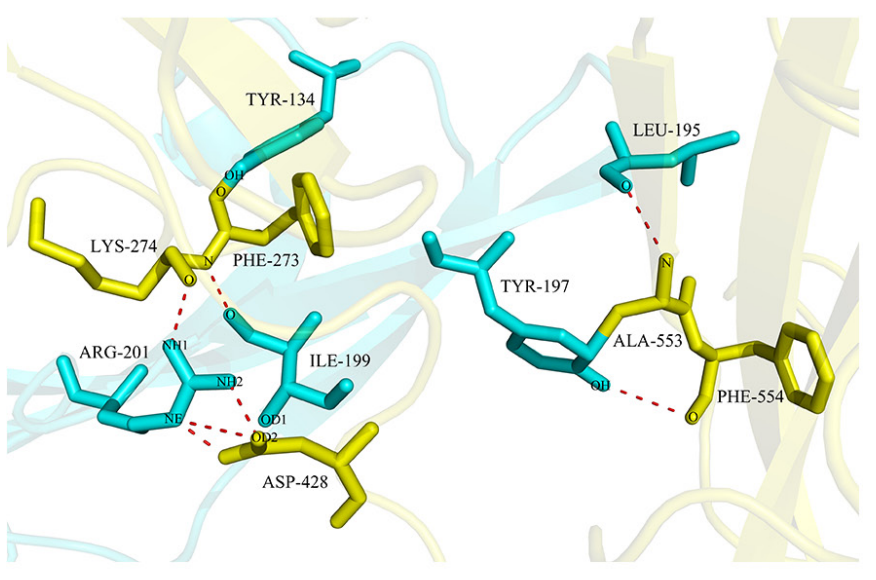

F

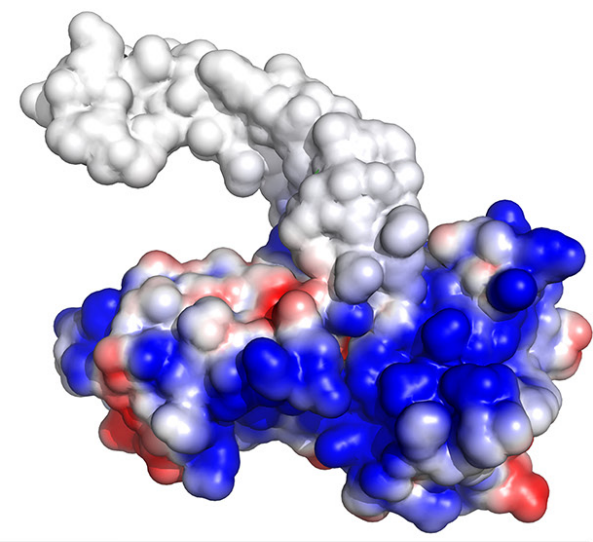

$-2.000$

Figure 6: Illustration of binding interactions between GDNF and NRP1. Interaction between GDNF and NRP1 based on protein structure docking performed by the ZDOCK server and visualized by PyMOL Molecular Graphics System. (A) A surface presentation of the GDNF-NRP1 binding interface. Blue: GDNF; yellow: NRP1. (B) Surface images of GDNF (Blue) and NRP1 (yellow) showing H-bond between amino acid residues of GDNF and NRP1 (red). (C) A ribbon and stick presentation of GDNF-NRP1 binding. Blue: GDNF; yellow: NRP1. (D) A stick presentation of the GDNF-NRP1 binding interface showing the $8 \mathrm{H}$-bonds between the corresponding amino acids. (E) Surface presentation showing electrostatic interaction between NRP1 and GDNF on one side. Red denotes negative charge whereas blue denotes positive charge. (F) Surface presentation showing electrostatic interaction between NRP1 and GDNF on the opposite side to that shown in E. 
Table 2: Summary of hydrogen bonding between GDNF and NRP1

\begin{tabular}{|c|c|c|c|c|c|c|c|}
\hline \multirow{2}{*}{ Hydrogen bond } & \multicolumn{3}{|c|}{ NRP1 } & \multicolumn{3}{|c|}{ GDNF } & \multirow{2}{*}{ distance $(\AA)$} \\
\hline & AA No. & $\mathbf{A A}$ & Atom & AA No. & $\mathbf{A A}$ & Atom & \\
\hline 1 & 273 & PHE & $\mathrm{O}$ & 134 & TYR & $\mathrm{OH}$ & 1.43 \\
\hline 2 & 554 & PHE & $\mathrm{O}$ & 197 & TYR & $\mathrm{OH}$ & 3.34 \\
\hline 3 & 428 & ASP & OD1 & 201 & ARG & NE & 3.29 \\
\hline 4 & 428 & ASP & OD2 & 201 & ARG & NE & 2.02 \\
\hline 5 & 274 & LYS & $\mathrm{O}$ & 201 & ARG & NH1 & 2.76 \\
\hline 6 & 428 & ASP & OD1 & 201 & ARG & NH2 & 2.19 \\
\hline 7 & 274 & LYS & $\mathrm{N}$ & 199 & ILE & $\mathrm{O}$ & 2.42 \\
\hline 8 & 553 & ALA & $\mathrm{N}$ & 195 & LEU & $\mathrm{O}$ & 2.87 \\
\hline
\end{tabular}

Note: AA: amino acid; O, OD1, OD2 and OH: oxygen; N, NE, NH1 and NH2: nitrogen;

Based on protein structure analysis of NRP1-GDNF binding by ZDOCK server and visualized by PyMOL Molecular Graphics System.

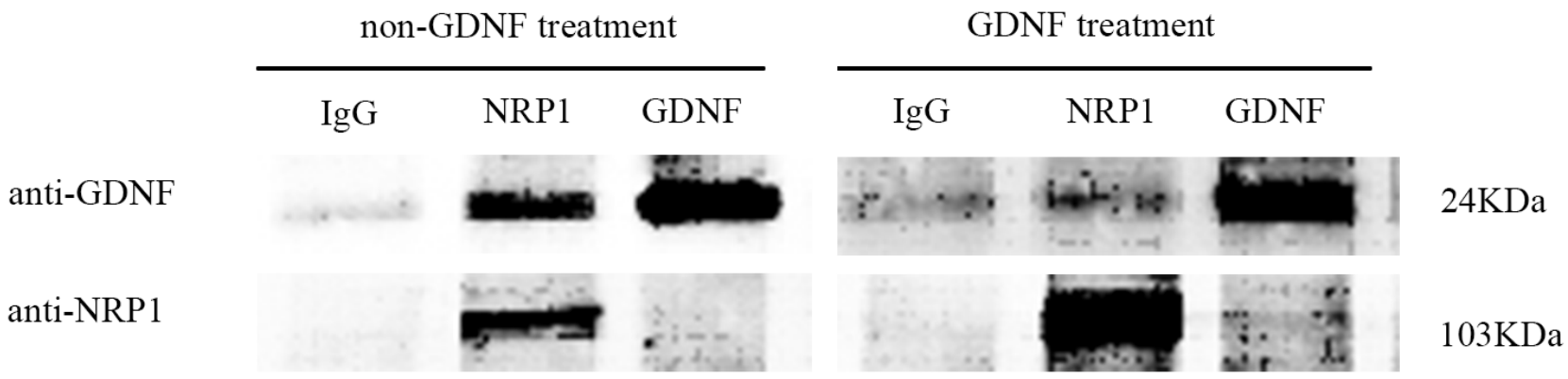

Figure 7: Co-immunoprecipitation analysis demonstrating NRP1 and GDNF binding. Western blot analysis showing results of Co-IP of membrane proteins from non-GDNF and GDNF treated (40 ng/ml) groups with either IgG (negative control), anti-NRP1 or anti-GDNF antibodies. NRP1 $(103 \mathrm{kDa})$ binds to GDNF $(24 \mathrm{kDa})$ in both non-GDNF and GDNF treatment groups. As shown, NRP1 is enriched in the GDNF treated group.

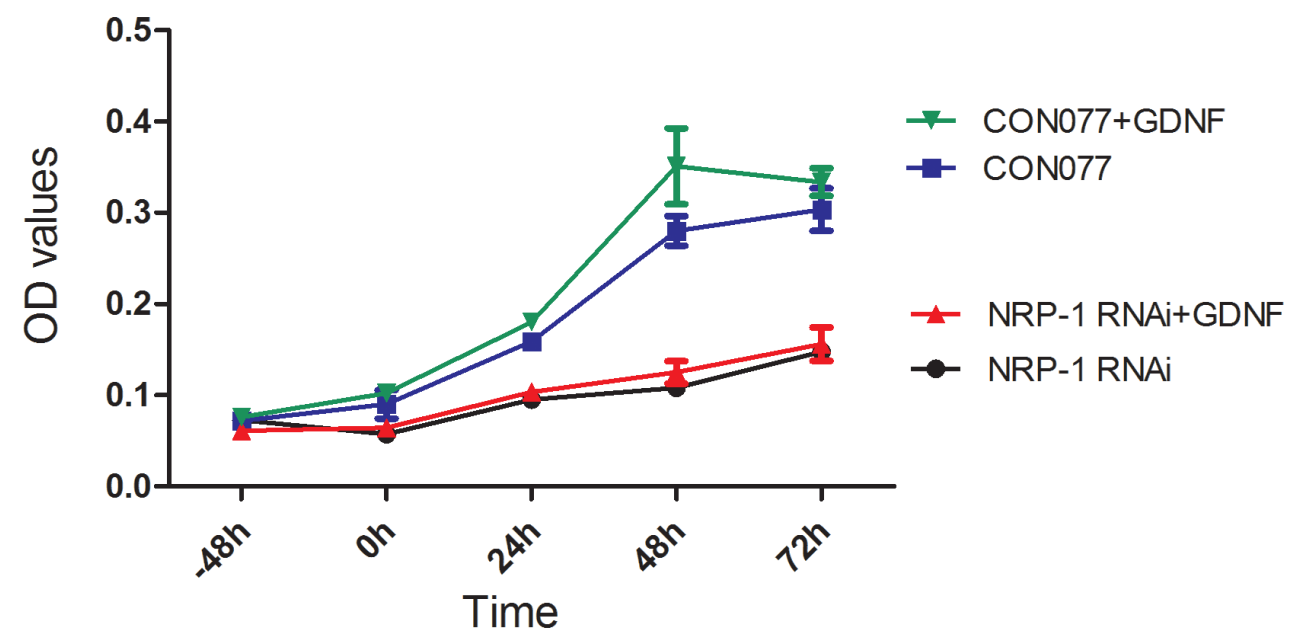

Figure 8: NRP1 RNAi reduces proliferation of GDNF-treated C6 rat glioma cells. C6 rat glioma cells were infected with lentiviruses containing NRP1 shRNA or CON077 (control shRNA) for $48 \mathrm{~h}$ and then treated with or without exogenous GDNF. Plot shows CCK-8 assay measurements of cell proliferation at -48, 0, 24, 48 and 72h. As shown, NRP1 knockdown demonstrated lower OD values than the CON077 group at all time points after adding exogenous GDNF. Data were analyzed as mean \pm SD from 3 replicate experiments. 
Table 3: Overall survival (OS) of high and low NRP1 expressing GBM patients

\begin{tabular}{lcccccc}
\hline Group & N & mean & sd & p25 & p50 & p75 \\
\hline 0 & 149 & 14.569 & 13.111 & 5.390 & 12.550 & 17.870 \\
1 & 16 & 8.120 & 4.031 & 4.580 & 8.215 & 10.825 \\
\hline Total & 165 & 13.944 & 12.660 & 5.160 & 11.830 & 17.480 \\
\hline
\end{tabular}

Note: group 0: low or normal NRP1 expressing GBM patient group; 1: high NRP1 expressing GBM patient group. $\mathrm{N}$ : samples number; sd: standard deviation; p25, p50 and p75: percentiles.

homology and are located on chromosome 10p12 and $2 q 34$, respectively. Both of them are composed of three domains, extracellular, transmembrane and intracellular. NRP1 plays an important role in the normal development of the cardiovascular and nervous system [22]. Takagi et al reported that NRP1 mRNAs were present in the optic ganglion cells and absent in non-neuronal cells in the central and peripheral nervous system [23]. In recent years, NRP1 overexpression has been reported in many diseases [24-26] including cancers [27, 28].

In glioma, increased NRP1 expression is observed in endothelial cells and the neoplastic astrocytes of GBM [29]. NRP1 overexpression is also reported in glioma cell lines, C6, U251 and U87 [30]. Immunofluorescence staining demonstrated higher NRP1 expression on the membrane of C6 glioma cells than normal rat astrocytes. Also, higher NRP1 mRNA levels were observed in human GBM brain samples compared to normal in the TGCA GBM dataset.

A

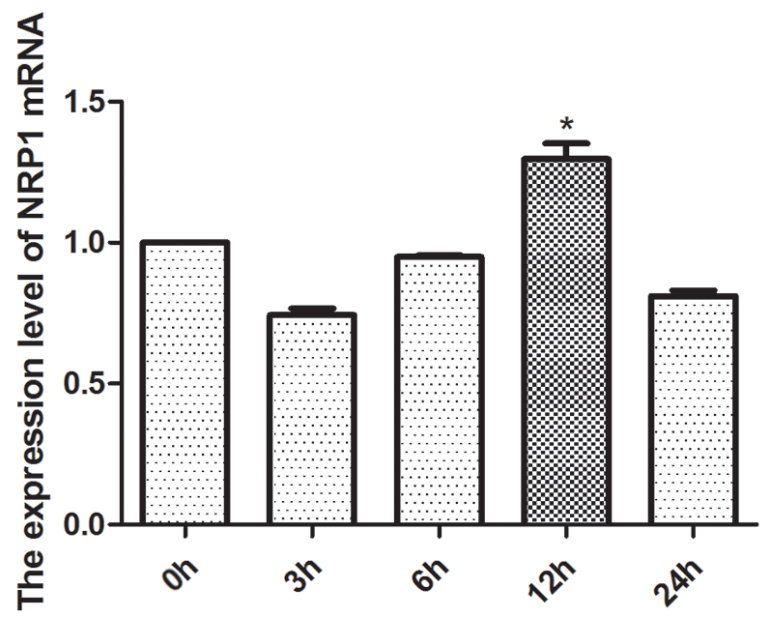

NRP1 mediates progression of a variety of tumors including gliomas $[31,32]$. It mediates the angiogenic effect of VEGF to provide nutrients for tumor growth $[33,34]$. In human glioma cells, VEGF-VEGFR2-NRP1 signaling promotes the growth of tumors $[35,36]$. In GBM, semaphorin3A (Sema3A)-NRP1 signaling mediates the invasion of cancer cells [37]. In U87MG glioma cells and vascular endothelial cells stimulated by hepatocyte growth factor, platelet-derived growth factor and VEGF, the intracellular domain of NRP1 induces tyrosine phosphorylation of $\mathrm{p} 130^{\mathrm{Cas}}$, which stimulates growth and invasion of gliomas [38-40].

Interestingly, GDNF and/or its putative receptor RET/NCAM crosstalk with the Semaphorins/VEGF family, which are the putative ligands of NRP1. Samaphorin3B interacts with GDNF signaling via NCAM to regulate axon guidance [41]. Sema4C-Plexin B2 signaling interacts with GDNF-RET signaling to regulate ureteric branching [42]. SEMA3A competes with
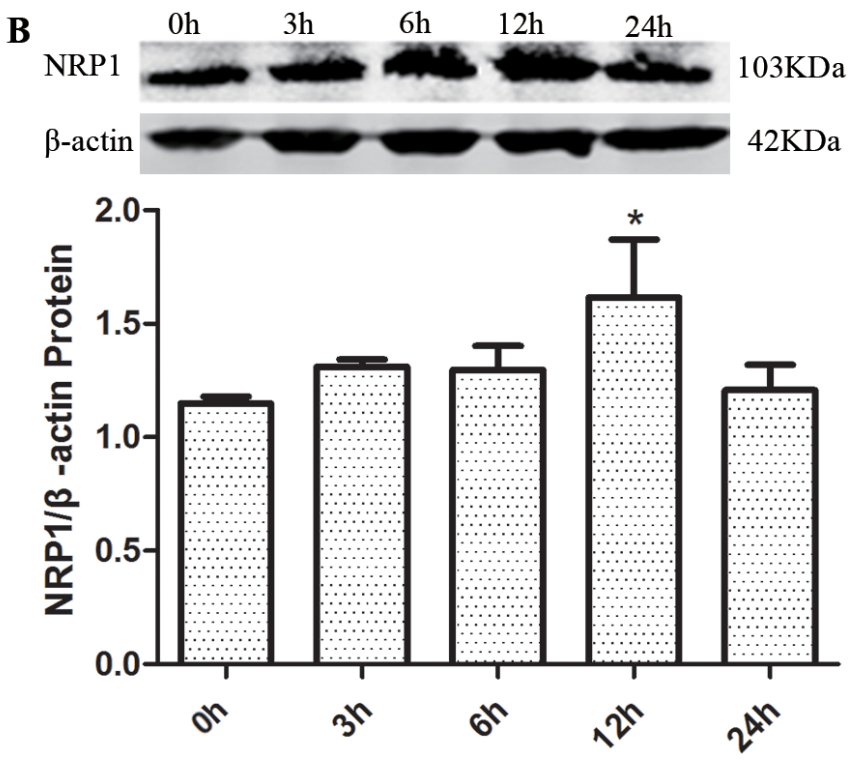

Figure 9: The effects of exogenous GDNF on NRP1 mRNA and protein expression in C6 cells. (A) Histogram shows relative NRP1 mRNA levels in C6 cells at 0,3, 6, 12 and 24h after treatment with $40 \mathrm{ng} / \mathrm{ml}$ GDNF. Relative levels plotted represent ratio of experiment group/control group. (B) Histogram shows quantification of relative NRP1 protein levels (ratio of NRP1/ $\beta$-actin) in C6 cells at $0,3,6,12$ and $24 \mathrm{~h}$ after treatment with $40 \mathrm{ng} / \mathrm{ml}$ GDNF. Representative western blot is also shown. The data represent the mean \pm SEM of three independent experiments. $* P<0.05$. 
Table 4: Disease-free survival (DFS) of high and low NRP1 expressing GBM patients

\begin{tabular}{lcccccc}
\hline Group & $\mathbf{N}$ & mean & sd & p25 & p50 & p75 \\
\hline 0 & 104 & 10.178 & 11.574 & 4.385 & 6.375 & 12.745 \\
1 & 15 & 3.749 & 2.351 & 2.300 & 2.890 & 4.760 \\
\hline Total & 119 & 9.367 & 11.054 & 3.190 & 5.850 & 10.940 \\
\hline
\end{tabular}

Note: group 0: low or normal NRP1 expressing GBM patient group; 1: high NRP1 expressing GBM patient group. $\mathrm{N}$ : samples number; sd: standard deviation; p25, p50 and p75: percentiles.

Table 5: Multivariate analysis of OS in comparison to high NRP1 levels

\begin{tabular}{lccccc}
\hline OS & Coeff. & Std. Err. & $\mathbf{z}$ & P>z & [95\% CI] \\
\hline group & 0.950 & 0.298 & 3.190 & 0.001 & $0.366-1.534$ \\
age & 0.025 & 0.007 & 3.440 & 0.001 & $0.011-0.039$ \\
gender & 0.032 & 0.185 & 0.180 & 0.861 & $-0.330-0.395$ \\
\hline
\end{tabular}

Note: OS:overall survival; CI: confidence interval; Coeff: coefficient; Std. Err: standard error; z: z-score.

Table 6: Multivariate analysis of DFS in comparison to high NRP1 levels

\begin{tabular}{lccccc}
\hline DFS & Coeff. & Std. Err. & $\mathbf{z}$ & P>z & [95\% CI] \\
\hline group & 1.291 & 0.338 & 3.820 & 0.000 & $0.629-1.954$ \\
age & 0.014 & 0.009 & 1.700 & 0.089 & $-0.002-0.031$ \\
gender & 0.211 & 0.245 & 0.860 & 0.387 & $-0.268-0.691$ \\
\hline
\end{tabular}

Note: DFS:disease-free survival; CI: confidence interval; Coeff: coefficient; Std. Err: standard error;; z: z-score.
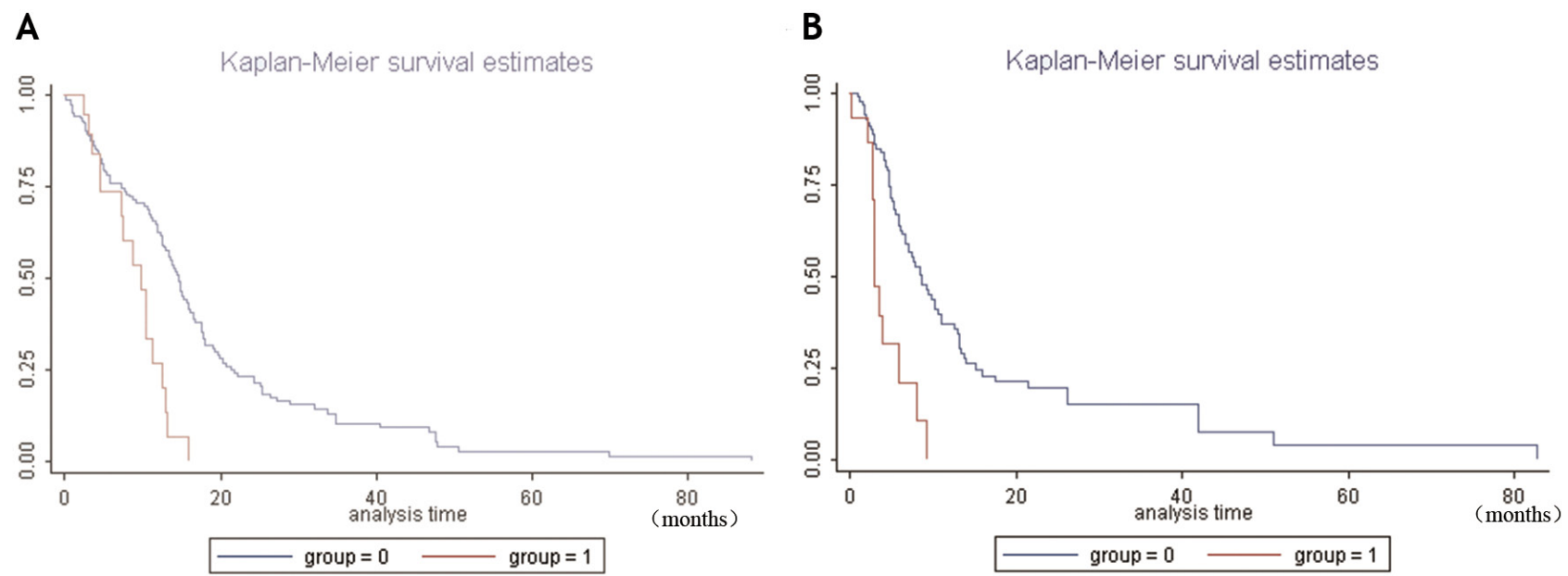

Figure 10: Kaplan-Meier survival analysis of GBM patients with high and low NRP1 mRNA levels. (A) Kaplan-Meier curves for overall survival showing high NRP1 mRNA expressing GBM patient group (group 1) and normal NRP1 expressing GBM patient group (group 0). (B) Kaplan-Meier curves for disease-free survival showing high NRP1 mRNA expressing GBM patient group (group 1) and normal NRP1 expressing GBM patient group (group 0). Note: abscissa: survival months of patients; ordinate: survival rate; $P<0.05$. 
VEGF165 for NRP1 binding and impairs GDNF signaling, whereas GDNF competes with VEGF-A signaling to inhibit ureteric bud branching morphogenesis [43]. GDNF also interacts with VEGF-VEGFR1 to increase human colon cancer cell motility [44]. VEGF-A/VEGFR2 cooperatively interacts with GDNF/RET signaling to induce ureteric bud cell proliferation and branching morphogenesis [45]. This suggests that NRP1, a putative receptor for Semaphorins/VEGF family, is a potential GDNF receptor.

Using laser scanning confocal microscopy, we observed that exogenous GDNF recruited NRP1 protein to the C6 glioma cell membrane. Coincidentally, stimulation of GDNF recruited RET to the lipid rafts resulting in RET/ Src association [46], and protecting RET from proteasomal degradation [47]. This dynamic event was required for effective GDNF signaling. Therefore, we postulate that the recruitment of NRP1 to the C6 glioma cell membrane is necessary for effective GDNF signaling.

We observed decreased proliferation in GDNFstimulated C6 glioma cells when NRP1 was knocked down. Further, exogenous GDNF increased the expression of NRP1 mRNA and protein. H Osada et al. reported that the overexpression of NRP1 gene predicted tumor progression and poor prognosis in glioma [48]. We analyzed the association of NRP1 mRNA levels with overall survival and disease-free survival of GBM patients in the TCGA database by multivariate proportional hazard model. Results showed that NRP1 was an independent risk factor for GBM. Also, high NRP1 levels were associated with poor OS and DFS as well as early recurrence in GBM patients. This suggests that GDNF-NRP1 signaling promotes GBM progression and results in poor prognosis.

In conclusion, we demonstrated that NRP1 was the binding receptor of GDNF in glioma cells with therapeutic potential.

\section{MATERIALS AND METHODS}

\section{C6 glioma cell line and primary astrocytes cultures}

The rat C6 glioma cell line (Chinese Academy of Sciences, Shanghai, China) was grown in DMEM/F-12 medium (Gibco, Carlsbad, CA, USA) supplemented with $10 \%$ fetal bovine serum (FBS, Gibco, Carlsbad, CA, USA), 100U/ml penicillin (Vicmed, Jiangsu, China) and $0.1 \mathrm{mg} / \mathrm{ml}$ streptomycin (Vicmed, Jiangsu, China) at $37^{\circ} \mathrm{C}$ and $5 \% \mathrm{CO}_{2}$.

The primary astrocytes were prepared from the cerebral cortex of $\sim 3$ day old newborn SpragueDawley (SD) rats using the Neural Tissue Dissociation Kit (NTDK; MiltenyiBiotec Inc., BergischGladbach, Germany) [49]. After microglia and oligodendrocytes were removed, the rest of the cells were stained with the primary rabbit anti-glial fibrillary acidic protein (GFAP) antibody (Cappel, 1:100) followed by the secondary antibody, Alexa Fluor488 - conjugated Affinipure goat anti-rabbit (Vicmed, Jiangsu, China, 1:200) and observed under the fluorescent microscope to confirm the presence of primary astrocytes. The isolated primary astrocytes were then cultured in DMEM/F-12 medium containing $10 \% \mathrm{FBS}$ at $37^{\circ} \mathrm{C}$ and $5 \% \mathrm{CO}_{2}$.

\section{Cell cycle analysis by flow cytometry}

Seven sets of C6 rat glioma cells were cultured in $\mathrm{DMEM} / \mathrm{F}-12$ medium containing $10 \% \mathrm{FBS}$ at $37^{\circ} \mathrm{C}$ with $5 \% \mathrm{CO}_{2}$ for $24 \mathrm{~h}$ in $100 \mathrm{~mm}$ culture dishes. Then, 6 sets were rinsed by PBS and grown in DMEM/F12 with $0.1 \%$ FBS (serum starvation medium), whereas 1 control set was grown in DMEM/F12 with 10\% FBS for 1-6 days. The cells were then fixed in anhydrous ethanol at $4{ }^{\circ} \mathrm{C}$ overnight, washed with PBS and incubated with $100 \mu \mathrm{g} / \mathrm{ml}$ RNAase (Tiangen Biotech, Beijing, China) in $500 \mu \mathrm{l}$ PBS at $37^{\circ} \mathrm{C}$ for $30 \mathrm{~min}$. The cells were then stained with 100 $\mu \mathrm{g} / \mathrm{ml}$ propidium iodide (PI; Sigma, cat\# P-4170) at $4^{\circ} \mathrm{C}$ for $30 \mathrm{~min}$ and analyzed by flow cytometry (FACSCalibur, BD Biosciences, San Jose, CA, USA).

To determine the effects of GDNF on cell cycle, C6 glioma cells were cultured in a $60 \mathrm{~mm}$ dish for $24 \mathrm{~h}$, and then starved for $48 \mathrm{~h}$. Then, the cells were treated with different concentrations of GDNF $(0,20,40,80$, and 100 $\mathrm{ng} / \mathrm{ml}$ ) and further cultured for 2 days followed by PI staining and FACS analysis as described above. Modfit software (Verity, Topsham, ME) was used to determine the percentage of G0/G1 and S phase cells.

\section{CCK8 cell viability assay}

The CCK-8 assay was used to determine the optimal GDNF concentration for maximal proliferation of $\mathrm{C} 6$ glioma cells. Briefly, the $\mathrm{C} 6$ glioma cells were cultured in $96-$ well plates for $24 \mathrm{~h}$ and then starved for $48 \mathrm{~h}$. Then, they were treated with various concentrations of GDNF $(0,0.1,1,10,20,40,80,100,200$ and $400 \mathrm{ng} / \mathrm{ml})$ and grown for 24,48 or $72 \mathrm{~h}$ (one plate was used at each time point with six replicates for each concentration). Then the cell viability assay was performed with the cell counting kit-8 assay kit (CCK-8; Dojindo Laboratories, Shanghai, China). The OD values were measured at $450 \mathrm{~nm}$ with a microplate reader (QuantBioTek Instruments, Winooski, VT, USA).

\section{EdU cell proliferation assay}

We performed the EdU assay using Cell Light EdU DNA imaging Kit (RiboBio Co., Ltd. Guangzhou, China) to analyze cell proliferation. C6 glioma cells were incubated with EdU for $24 \mathrm{~h}$ after appropriate treatments with different concentrations of GDNF. The percentage of $\mathrm{EdU}^{+} \mathrm{C} 6$ cells was determined from the images. 


\section{Total, membrane and nuclear proteins extraction}

Total proteins extraction: Cells were collected, washed with cold PBS and centrifuged at $3000 \mathrm{rpm}$ for 5 minutes. Then, the centrifugal precipitation was permeabilized by Radio Immunoprecipitation Assay (RIPA) lysis buffer (50mM Tris (pH 7.4), $150 \mathrm{mM} \mathrm{NaCl}$, $1 \%$ Triton X-100, 1\% sodium deoxycholate, $0.1 \%$ SDS, sodium orthovanadate, sodium fluoride, EDTA and leupeptin; Beyotime, China) and Phenylmethanesulfonyl fluoride (PMSF) (100:1), and further incubated on the ice for 30 minutes (vertexing every 5 minutes) at $4^{\circ} \mathrm{C}$. Finally, after centrifugation at $12,000 \mathrm{rpm}$ for $30 \mathrm{~min}$ at $4^{\circ} \mathrm{C}$ and removing the supernatant, the precipitation (total proteins) were transfered to a new tube and stored at $-80^{\circ} \mathrm{C}$.

Preparation of nuclear fractions: The nuclear proteins were prepared according to instructions of Nuclear and Cytoplasmic Protein Extraction Kit (Beyotime, China, P0027). Briefly, the cells were scraped with cold PBS and resuspended in buffer A with PMSF $(100: 1)$, vortexed and incubated on the ice for $10 \mathrm{~min}$. Then the pellet was incubated with buffer B for $1 \mathrm{~min}$. Further, after centrifugation at $16000 \mathrm{rpm}$ for $5 \mathrm{~min}$ at $4^{\circ} \mathrm{C}$, the supernatant (cytoplasmic fraction) was removed and the pellet was resuspended in nuclear extraction buffer $\mathrm{C}$ with PMSF (100:1) for 30 min (vertexing every 5 minutes) at $4^{\circ} \mathrm{C}$, Finally, after centrifugation at $16,000 \mathrm{rpm}$ for $10 \mathrm{~min}$ at $4^{\circ} \mathrm{C}$, the supernatant (nuclear fraction) was stored at $-80^{\circ} \mathrm{C}$. At the same time, the extracted proteins were analyzed by western blot using rabbit anti-Histone H3 antibody (BS1660, bioworld, US, 1:500) to confirm the purity of the nuclear fractions.

Membrane proteins extraction: Membrane proteins were extracted from $\sim 0.5 \mathrm{~g}$ C6 glioma cells and $0.2 \mathrm{~g}$ normal primary astrocytes using the Mem-PER ${ }^{\text {TM }}$ Eukaryotic Membrane Protein Extraction Kit (89826, Thermo Scientific, USA) according to manufacturer's instructions. The proteins were quantitated. The purity of membrane fractions was determined by western blot using mouse anti-alpha 1 Sodium Potassium ATPase $(\mathrm{Na} / \mathrm{K}$ ATPase, ab7671, Abcam, 1:250).

\section{GST pull-down assay}

The membrane proteins from rat $\mathrm{C} 6$ glioma cells (C6) or primary astrocytes (AST) were resuspended with $400 \mu \mathrm{l}$ PBS and divided into 2 groups. Among them, 300 $\mu \mathrm{l}$ was mixed with $15 \mu \mathrm{g}$ glutathione $\mathrm{S}$-transferase tagged GDNF (GST-GDNF) and $100 \mu \mathrm{l}$ was mixed with $5 \mu \mathrm{g}$ GST alone. The 4 different groups, namely, C6 GDNF-GST, C6 GST, AST GDNF-GST and AST GST were gently shaken for $1 \mathrm{~h}$ at $4^{\circ} \mathrm{C}$. Then, $60 \mu \mathrm{l}$ and $20 \mu \mathrm{l} \mathrm{GST}$ beads (Promega, V8611, USA) were added to the groups with GST-GDNF and GST, respectively, followed by overnight shaking at $4^{\circ} \mathrm{C}$. Then, the 4 groups were cleaned thrice with PBS and eluted with $60 \mu \mathrm{l}$ and $20 \mu \mathrm{l}$ elution buffer $(50 \mathrm{mM}$ glutathione in 50mM Tris, pH8.1), respectively.
The eluted samples were boiled in SDS-PAGE loading buffer and $12 \%$ SDS-PAGE was run at $90 \mathrm{~V}$ for $20 \mathrm{~min}$. When loading buffer in the samples had run to at least $1 / 3^{\text {rd }}$ of the sepration gel, according to the instructions for the Fast Silver Stain Kit (P0017S, Beyotime, China), the gel was immersed successively in fixation fluid $(50 \%$ ethanol, $10 \%$ acetic acid and $40 \% \mathrm{DDH}_{2} \mathrm{O}$ ), $30 \%$ ethanol, $\mathrm{DDH}_{2} \mathrm{O}, 100 \mathrm{ml}$ sensitizer solution, $\mathrm{DDH}_{2} \mathrm{O}, 100 \mathrm{ml}$ silver stain solution, $\mathrm{DDH}_{2} \mathrm{O}$, silver color-substrate solution, silver stop buffer and $\mathrm{DDH}_{2} \mathrm{O}$. All the steps were carried out with constant shaking at room temperature for several minutes. Finally, the silver stained gels were stored in $\mathrm{DDH}_{2} \mathrm{O}$.

\section{Liquid chromatography-tandem mass spectrometry}

The proteins were in-gel digested by $0.01 \mu \mathrm{g} / \mu \mathrm{l}$ trypsin at $37^{\circ} \mathrm{C}$ overnight using the filter aided sample preparation (FASP) technique. Peptide liquid phase separation was performed with the Prominence nano (LC-20AD, SHIMADZU) and processed by electrospray ionization (ESI) in the Q-EXACTIVE (QE) mass spectrometer (Thermo Fisher Scientific, San Jose, CA). The mass spectral files were analyzed using the Uniprot rat database (http://www.uniprot.org/) by the Proteome Discoverer ${ }^{\mathrm{TM}}$ Software 1.4 (Thermo Fisher Scientific). Finally, the protein identification results were verified by analyzing the distribution of peptides, peptide charge and coverage, protein abundance and abundance correlation between samples.

\section{Bioinformatics analysis}

The differentially expressed proteins (DEPs) of C6 rat glioma cells and primary rat astrocytes, identified from the MS, were compared using the GO database of the PANTHER Classification System [50] to identify the potential glioma specific receptors for GDNF.

\section{Immunofluorescence \& confocal miroscopy}

C6 and primary rat astrocytes were washed thrice with PBS and fixed with $4 \%$ paraformaldehyde for 45 $\mathrm{min}$. Then, the fixed cells were permeabilized for $5 \mathrm{~min}$ at room temperature with $0.3 \%$ TritonX-100 and blocked with $10 \%$ normal donkey serum in PBS for $30 \mathrm{~min}$. Then, they were incubated with primary antibodies (rabbit antiNRP1, ab81321, Abcam, 1:250; mouse anti-alpha $1 \mathrm{Na} / \mathrm{K}$ ATPase, ab7671, Abcam, 1:250) at $4^{\circ} \mathrm{C}$ overnight. The cells were washed with PBS followed by incubation with the corresponding secondary antibodies (Rhodamine-conjugated goat anti-rabbit, 1:1000; AlexaFluor 488-conjugated goat anti-mouse, Life Technologies, 1:1000) for $1 \mathrm{~h}$ at room temperature in the dark. Fluorescence images were captured with fluorescence (Olympus, IX71, Japan) or confocal laser fluorescence (Olympus, FV10i, Japan) microscopes. 


\section{Oncomine database analysis}

To identify changes in gene expression in GBM, we used the Oncomine (http://www.oncomine.org) cancer microarray database $[51,52]$. To show the target genes' mRNA levels of Brain GBM vs. Normal Brain, we used 'Brain Glioblastoma vs. Normal Analysis' as a filter and identified 1 brain microarray in the TGCA database with 557 samples and 12,624 measured genes (TCGA Brain, No Associated Paper, 2013). Then, we used 'target genes' as a filter to explore the changes in gene expression between GBM and normal brains.

\section{Co-immunoprecipitation}

Protein A/G-agarose beads were pre-incubated with $10 \mathrm{ug} / \mathrm{ml}$ anti-GDNF, 1:100 anti-NRP1 or IgG antibodies for $6 \mathrm{~h}$ at $4^{\circ} \mathrm{C}$. Then, membrane protein samples from $\mathrm{C} 6$ glioma cells treated with or without $40 \mathrm{ng} / \mathrm{ml}$ GDNF were added with the protein $\mathrm{A} / \mathrm{G}$-agarose beads and various antibodies, and rocked at $4^{\circ} \mathrm{C}$ overnight. Further, the beads were washed thrice with loading buffer and boiled in 1x SDS loading buffer for $1000 \mathrm{~g}$. After cooling to the room temperature, the samples were centrifuged $(10000 \mathrm{~g})$ for $3 \mathrm{~min}$ at $4^{\circ} \mathrm{C}$ and the supernatant was stored at $-20^{\circ} \mathrm{C}$. Finally, the corresponding Western blot experiments were performed using anti-GDNF or anti-NRP1 (details see "Western blot analysis" paragraph in this section).

\section{Molecular modeling}

We identified the 3D structures of GDNF and NRP1 from the Protein Data Bank (PDB). 4UX8 is electron microscopy structure of the GDNF-GFRA1-RET complex with residues 78-211 of the D chain of GDNF [53]. 2ORX is X-ray diffraction structure of amino acid residues 273-586 of NRP1 (chain A) consisting of the F5/8 type $\mathrm{C} 1$ and $\mathrm{C} 2$ domains [54]. For molecular modeling, the D chain of 4UX8 and the A chain of 2ORX were prepared by the PyMOL Molecular Graphics System (version 0.99 Schrödinger, LLC) and the histidine residues were protonated at $\mathrm{pH} 6.5$ using the PDB2PQR server 6 [55]. Then, NRP1-active sites were found with the Active Site prediction server (http:// www.scfbio-iitd.res.in/dock/ActiveSite.jsp) and the largest active pocket was chosen to dock. Further, the GDNF and NRP1 proteins were docked using the ZDOCK Server [56]. Finally, the docking results were analytically visualized by the PyMOL software with all hydrogen bonds and their corresponding residues labeled. In addition, the electrostatic interactions between NRP1 and GDNF were performed by the Adaptive Poisson-Boltzmann Solver (APBS) plug-in of the PyMOL software.

\section{NRP1 knockdown in C6 cells by lentiviral RNAi}

The RNAi for rat NRP1 (5'-GGACAGAGACT GCAAGTAT-3') was generated with the Block-it RNAi design program (Invitrogen, Carlsbad, CA, USA), whereas the control RNAi was generated using a scrambled sequence (5'-TTCTCCGAACGTGTCACGT-3') ensuring no homology with rat genome. The RNAi sequences were cloned into GV248 (GeneChem, Shanghai, China) to generate lentiviral shRNA vectors. Both the expression vectors and package vectors were then transfected into 293T cells by Lipo2000 (Invitrogen, USA). The lentivirus containing supernatants were harvested, denoted as GV248-NRP1-shRNA-LV and CON077-negative-shRNA$\mathrm{LV}$, respectively. The lentiviruses were concentrated by ultracentrifugation and their titers were determined (LVNRP1-RNAi, 5e ${ }^{8} \mathrm{TU} / \mathrm{ml}$; CON077-negative-shRNA-LV, $\left.1 \mathrm{e}^{9} \mathrm{TU} / \mathrm{ml}\right)$.

For lentivirus infections, the C6 glioma cells $\left(4 \times 10^{3}\right.$ cells/well) were cultured overnight in 96 -well microplates. The diluted lentiviruses in $0.2 \mathrm{ml}$ complete medium with $10 \mu \mathrm{g} / \mathrm{ml}$ polybrene were added to C6 cells and cultured for $12 \mathrm{~h}$ at $37^{\circ} \mathrm{C}$. The medium containing virus was replaced with fresh medium. Successfully infected cells were identified by observing GFP expression in a fluorescent microscope (Olympus, IX71, Japan).

\section{Western blot analysis}

After blocking by $5 \%$ skimmed milk, the samples were incubated with primary antibody (rabbit antiNRP1, ab81321, Abcam, 1:250; mouse anti-alpha $1 \mathrm{Na} /$ K-ATPase, ab7671, Abcam, 1:250; rabbit anti-GDNF, ab18956, Abcam, 1:100; mouse anti- $\beta$-actin, sc47778, Santa cruz, 1:1000; rabbit anti-Histone H3 antibody, BS1660, bioworld, 1:500) at $4^{\circ} \mathrm{C}$ overnight [57]. Then, the samples were incubated with IRdye secondary antibodies (goat anti-Rabbit, LI-COR, Odyssey, 1:1000; goat antiMouse, LI-COR, Odyssey, 1:1000) at room temperature for $2 \mathrm{~h}$. Finally, the protein bands were scanned by Odyssey imaging system (LI-COR, USA) and quantified with ImageJ software (National Institutes of Health, USA).

\section{QRT-PCR}

Total RNA was isolated from C6 glioma cells and its concentration and quality was determined with Nanodrop ND-1000 spectrophotometer (NanoDrop Technologies, Wilmington, DE, USA) and gel analysis. Then, the RNA samples were reverse transcribed to cDNA using Transcriptor First Strand cDNA synthesis kit (Roche Applied Science, Penzberg, Germany). Then, real time PCR was performed to analyze the expression of NRP1 using the SYBR Green PCR master mix (Roche Applied Science, Mannheim, Germany). The $20 \mu \mathrm{l}$ reaction mixture included $10 \mu 12 \times \mathrm{SYBR}^{\circledR}$ Premix Ex Taq (Takara, China), $0.5 \mu \mathrm{l}$ each of $10 \mu \mathrm{M}$ forward and reverse primers, $2 \mu \mathrm{L}$ cDNA template and $7 \mu \mathrm{L}$ RNase-free $\mathrm{H}_{2} \mathrm{O}$. The PCR 
conditions included initial denaturation at $95^{\circ} \mathrm{C}$ for $5 \mathrm{~min}$ followed by 45 cycles of $95^{\circ} \mathrm{C}$ for $10 \mathrm{sec}, 60^{\circ} \mathrm{C}$ for $15 \mathrm{sec}$ and $72^{\circ} \mathrm{C}$ for $15 \mathrm{sec}$.

The mRNA data were normalised to $\beta$-actin. The primers for NRP1 and $\beta$-actin were as follows:

\section{$\beta$-actin: Forward: 5-AGCCATGTACGTAGC CATCCA-3 \\ Reverse: 5-TCTCCGGAGTCCATC ACAATG-3 \\ NRP1: Forward: 5-GGAGCTACTGGGCTG TGAAG-3 \\ Reverse: 5-ATGTCGGGAACTCTGA TTGG-3}

\section{Survival analysis}

The dataset of Glioblastoma Multiforme was obtained via cBioportal from the TCGA website (http:// cancergenome.nih.gov) [58, 59]. Then, median expression of the mRNAs was determined (RNA Seq V2 RSEM). Patients were divided into 2 groups, namely, high NRP1 expression group and the control group. The two-sample rank-sum test and multivariate proportional hazard model analysis were performed with the overall survival (OS) and disease-free survival (DFS) data of the GBM patients and Kaplan-Meier curves were constructed.

\section{Statistical analysis}

Statistical analysis was performed using SPSS 17.0 for Windows. The data were presented as mean \pm standard deviation obtained from three independent experiments. One-way ANOVA and Tukey's post-hoc analysis were used to determine the differences between groups. $P<0.05$ was considered statistically significant.

\section{Abbreviations}

GBM, Glioblastoma; GDNF, Glial cell linederived neurotrophic factor; NRP1, neuropilin-1; CNS, central nervous system; GFL, GDNF family of ligands; GFRA1, GDNF family receptor alpha 1; RET, receptor tyrosine kinase; NCAM, neural cell adhesion molecule; PPIs, protein-protein interactions; LC-MS/MS, liquid chromatography-tandem mass spectrometry; GO, Gene Ontology; DMEM/F-12, Dulbecco's Modified Eagle Medium/Nutrient Mixture F-12; FBS, fetal bovine serum; SD, Sprague-Dawley; GST, glutathione S-transferase; NTDK, Neural Tissue Dissociation Kits; GFAP, glial fibrillary acidic protein; FASP, filter aided sample preparation; PI, propidium iodide; CCK8 assay, cell counting kit-8 assay; OD values, optical density values; EdU, 5-ethynyl-2'-deoxyuridine; SDS-PAGE, sodium salt-Polyacrylamide gel electrophoresis; ESI, electrospray ionization; PANTHER, Protein ANalysis THrough Evolutionary Relationships; PDB, Protein Data Bank; LV, lentivirus; AST, primary astrocytes; ITGB1,
Integrin Subunit Beta1; LFQ, Label-free quantitative; CDH2, Cadherin-2; SDC3, Syndecan-3; ATRN, Attractin; IF, immunofluorescent; OS, overall survival; DFS, disease-free survival; Sema3A, semaphorin3A; DAs, dopaminergic neurons; DEPs, differentially expressed proteins; Co-IP, Co-Immunoprecipitation; VEGF, Vascular Endothelial Growth Factor; VEGFR, Vascular Endothelial Growth Factor Receptor; DAPI, 4',6-diamidino-2phenylindole; FC, Fold Change.

\section{Author contributions}

Shen Sun: Study conception and design, Project Administration, drafting and submission of manuscript.

Yu Lei: Performed most experiments, data collection and analysis.

Qi Li: Performed almost half of experiments and literature search.

Yue Wu: Bioinformatics analyses and internet data collection.

Lin Zhang: assistance in experiments and data collection.

Pei-Pei Mu: assistance in experiments.

Guang-Quan Ji: Organizing pictures and tables.

Chuan-Xi Tang: Statistical analysis.

Yu-Qian Wang: Primary rat astrocytes culture.

Jian Gao: Molecular modeling; Funding Acquisition.

Jin Gao: Manuscript review and edit.

Li Li: Manuscript review and edit.

Lang Zhuo: Survival analysis.

Yun-Qing Li: Critical revision.

Dian-Shuai Gao: Funding, project supervision, study conception and design.

\section{ACKNOWLEDGMENTS}

This project was supported by the National Natural Science Foundation of China (Grant numbers 81372698), Natural Science Foundation of Jiangsu Province (BK20130212), a project funded by the Priority Academic Program Development (PAPD) of Jiangsu Higher Education Institutions, and the Natural Science Foundation of Jiangsu Province (Grants No BK20140225).

\section{CONFLICTS OF INTEREST}

The authors declare no conflicts of interest.

\section{REFERENCES}

1. Furnari FB, Fenton T, Bachoo RM, Mukasa A, Stommel JM, Stegh A, Hahn WC, Ligon KL, Louis DN, Brennan C, Chin L, DePinho RA, Cavenee WK. Malignant astrocytic glioma: genetics, biology, and paths to treatment. Genes Dev. 2007; 21:2683-710. 
2. Van Meir EG, Hadjipanayis CG, Norden AD, Shu HK, Wen PY, Olson JJ. Exciting new advances in neuro-oncology: the avenue to a cure for malignant glioma. CA Cancer J Clin. 2010; 60:166-93.

3. Wiesenhofer B, Stockhammer G, Kostron H, Maier $\mathrm{H}$, Hinterhuber $\mathrm{H}$, Humpel C. Glial cell line-derived neurotrophic factor (GDNF) and its receptor (GFR-alpha 1) are strongly expressed in human gliomas. Acta Neuropathol. 2000; 99:131-37.

4. Wiesenhofer B, Weis C, Humpel C. Glial cell line-derived neurotrophic factor (GDNF) is a proliferation factor for rat C6 glioma cells: evidence from antisense experiments. Antisense Nucleic Acid Drug Dev. 2000; 10:311-21.

5. Lodish HB, Zipursky SL, Matsudaira P, Baltimore D, Darnell J. Molecular Cell Biology. New York, USA: W.H. Freeman; 2000.

6. Trupp M, Raynoschek C, Belluardo N, Ibáñez CF. Multiple GPI-anchored receptors control GDNF-dependent and independent activation of the c-Ret receptor tyrosine kinase. Mol Cell Neurosci. 1998; 11:47-63.

7. Durbec P, Marcos-Gutierrez CV, Kilkenny C, Grigoriou M, Wartiowaara K, Suvanto P, Smith D, Ponder B, Costantini F, Saarma M, Sariola H, Pachnis V. GDNF signalling through the Ret receptor tyrosine kinase. Nature. 1996; 381:789-93.

8. Airaksinen MS, Saarma M. The GDNF family: signalling, biological functions and therapeutic value. Nat Rev Neurosci. 2002; 3:383-94.

9. Sariola H, Saarma M. Novel functions and signalling pathways for GDNF. J Cell Sci. 2003; 116:3855-62.

10. Parkash V, Leppänen VM, Virtanen H, Jurvansuu JM, Bespalov MM, Sidorova YA, Runeberg-Roos P, Saarma M, Goldman A. The structure of the glial cell line-derived neurotrophic factor-coreceptor complex: insights into RET signaling and heparin binding. J Biol Chem. 2008; 283:35164-72.

11. Paratcha G, Ledda F, Ibáñez CF. The neural cell adhesion molecule NCAM is an alternative signaling receptor for GDNF family ligands. Cell. 2003; 113:867-79.

12. Bespalov MM, Sidorova YA, Tumova S, Ahonen-Bishopp A, Magalhães AC, Kulesskiy E, Paveliev M, Rivera C, Rauvala H, Saarma M. Heparan sulfate proteoglycan syndecan-3 is a novel receptor for GDNF, neurturin, and artemin. J Cell Biol. 2011; 192:153-69.

13. Keskin O, Tuncbag N, Gursoy A. Predicting Protein-Protein Interactions from the Molecular to the Proteome Level. Chem Rev. 2016; 116:4884-909.

14. Mi H, Huang X, Muruganujan A, Tang H, Mills C, Kang D, Thomas PD. PANTHER version 11: expanded annotation data from Gene Ontology and Reactome pathways, and data analysis tool enhancements. Nucleic Acids Res. 2017; 45:D183-89.

15. Cao JP, Yu JK, Li C, Sun Y, Yuan HH, Wang HJ, Gao DS. Integrin betal is involved in the signaling of glial cell line-derived neurotrophic factor. J Comp Neurol. 2008; 509:203-10.

16. Cao JP, Wang HJ, Yu JK, Yang H, Xiao CH, Gao DS. Involvement of NCAM in the effects of GDNF on the neurite outgrowth in the dopamine neurons. Neurosci Res. 2008; 61:390-97.

17. Zuo T, Qin JY, Chen J, Shi Z, Liu M, Gao X, Gao D. Involvement of $\mathrm{N}$-cadherin in the protective effect of glial cell line-derived neurotrophic factor on dopaminergic neuron damage. Int J Mol Med. 2013; 31:561-68.

18. Teesalu T, Sugahara KN, Kotamraju VR, Ruoslahti E. C-end rule peptides mediate neuropilin-1-dependent cell, vascular, and tissue penetration. Proc Natl Acad Sci USA. 2009; 106:16157-62.

19. Zhang L, Parry GC, Levin EG. Inhibition of tumor cell migration by LD22-4, an N-terminal fragment of $24-\mathrm{kDa}$ FGF2, is mediated by Neuropilin 1. Cancer Res. 2013; 73:3316-25.

20. Starzec A, Ladam P, Vassy R, Badache S, Bouchemal N, Navaza A, du Penhoat CH, Perret GY. Structure-function analysis of the antiangiogenic ATWLPPR peptide inhibiting VEGF(165) binding to neuropilin-1 and molecular dynamics simulations of the ATWLPPR/neuropilin-1 complex. Peptides. 2007; 28:2397-402.

21. Nakamura F, Goshima Y. Structural and functional relation of neuropilins. Adv Exp Med Biol. 2002; 515:55-69.

22. Kitsukawa T, Shimono A, Kawakami A, Kondoh H, Fujisawa H. Overexpression of a membrane protein, neuropilin, in chimeric mice causes anomalies in the cardiovascular system, nervous system and limbs. Development. 1995; 121:4309-18.

23. Takagi S, Hirata T, Agata K, Mochii M, Eguchi G, Fujisawa $\mathrm{H}$. The A5 antigen, a candidate for the neuronal recognition molecule, has homologies to complement components and coagulation factors. Neuron. 1991; 7:295-307.

24. Thomas S, Vanuystel J, Gruden G, Rodríguez V, Burt D, Gnudi L, Hartley B, Viberti G. Vascular endothelial growth factor receptors in human mesangium in vitro and in glomerular disease. J Am Soc Nephrol. 2000; 11:1236-43.

25. Ikeda M, Hosoda Y, Hirose S, Okada Y, Ikeda E. Expression of vascular endothelial growth factor isoforms and their receptors Flt-1, KDR, and neuropilin-1 in synovial tissues of rheumatoid arthritis. J Pathol. 2000; 191:426-33.

26. Ishida S, Shinoda K, Kawashima S, Oguchi Y, Okada Y, Ikeda E. Coexpression of VEGF receptors VEGF-R2 and neuropilin-1 in proliferative diabetic retinopathy. Invest Ophthalmol Vis Sci. 2000; 41:1649-56.

27. Banerjee SK, Zoubine MN, Tran TM, Weston AP, Campbell DR. Overexpression of vascular endothelial growth factor164 and its co-receptor neuropilin-1 in estrogeninduced rat pituitary tumors and GH3 rat pituitary tumor cells. Int J Oncol. 2000; 16:253-60.

28. Latil A, Bièche I, Pesche S, Valéri A, Fournier G, Cussenot O, Lidereau R. VEGF overexpression in clinically localized 
prostate tumors and neuropilin-1 overexpression in metastatic forms. Int J Cancer. 2000; 89:167-71.

29. Broholm H, Laursen H. Vascular endothelial growth factor (VEGF) receptor neuropilin-1's distribution in astrocytic tumors. APMIS. 2004; 112:257-63.

30. Chen L, Miao W, Tang X, Zhang H, Wang S, Luo F, Yan J. The expression and significance of neuropilin-1 (NRP-1) on glioma cell lines and glioma tissues. J Biomed Nanotechnol. 2013; 9:559-63.

31. Zhang G, Chen L, Sun K, Khan AA, Yan J, Liu H, Lu A, Gu N. Neuropilin-1 (NRP-1)/GIPC1 pathway mediates glioma progression. Tumour Biol. 2016; 37:13777-88.

32. Hu B, Guo P, Bar-Joseph I, Imanishi Y, Jarzynka MJ, Bogler O, Mikkelsen T, Hirose T, Nishikawa R, Cheng SY. Neuropilin-1 promotes human glioma progression through potentiating the activity of the HGF/SF autocrine pathway. Oncogene. 2007; 26:5577-86.

33. Miao $\mathrm{HQ}$, Lee $\mathrm{P}$, Lin $\mathrm{H}$, Soker $\mathrm{S}$, Klagsbrun $\mathrm{M}$. Neuropilin-1 expression by tumor cells promotes tumor angiogenesis and progression. FASEB J. 2000; 14:2532-39.

34. Mac Gabhann F, Popel AS. Targeting neuropilin-1 to inhibit VEGF signaling in cancer: comparison of therapeutic approaches. PLOS Comput Biol. 2006; 2:e180.

35. Barr MP, Byrne AM, Duffy AM, Condron CM, Devocelle M, Harriott P, Bouchier-Hayes DJ, Harmey JH. A peptide corresponding to the neuropilin-1-binding site on VEGF(165) induces apoptosis of neuropilin-1-expressing breast tumour cells. Br J Cancer. 2005; 92:328-33.

36. Hamerlik P, Lathia JD, Rasmussen R, Wu Q, Bartkova J, Lee M, Moudry P, Bartek J Jr, Fischer W, Lukas J, Rich JN, Bartek J. Autocrine VEGF-VEGFR2-Neuropilin-1 signaling promotes glioma stem-like cell viability and tumor growth. J Exp Med. 2012; 209:507-20.

37. Bagci T, Wu JK, Pfannl R, Ilag LL, Jay DG. Autocrine semaphorin $3 \mathrm{~A}$ signaling promotes glioblastoma dispersal. Oncogene. 2009; 28:3537-50.

38. Evans IM, Yamaji M, Britton G, Pellet-Many C, Lockie C, Zachary IC, Frankel P. Neuropilin-1 signaling through p130Cas tyrosine phosphorylation is essential for growth factor-dependent migration of glioma and endothelial cells. Mol Cell Biol. 2011; 31:1174-85.

39. Chen L, Miao W, Zhang H, Zeng F, Cao C, Qiu R, Yang J, Luo F, Yan J, Lv H, Xu Q. The inhibitory effects of a monoclonal antibody targeting neuropilin-1 on adhesion of glioma cells to fibronectin. J Biomed Nanotechnol. 2014; 10:3373-80.

40. Frankel P, Pellet-Many C, Lehtolainen P, D'Abaco GM, Tickner ML, Cheng L, Zachary IC. Chondroitin sulphatemodified neuropilin 1 is expressed in human tumour cells and modulates 3D invasion in the U87MG human glioblastoma cell line through a p130Cas-mediated pathway. EMBO Rep. 2008; 9:983-89.

41. Charoy C, Nawabi H, Reynaud F, Derrington E, Bozon M, Wright K, Falk J, Helmbacher F, Kindbeiter K, Castellani
V. gdnf activates midline repulsion by Semaphorin3B via NCAM during commissural axon guidance. Neuron. 2012; 75:1051-66.

42. Perälä N, Jakobson M, Ola R, Fazzari P, Penachioni JY, Nymark M, Tanninen T, Immonen T, Tamagnone L, Sariola H. Sema4C-Plexin B2 signalling modulates ureteric branching in developing kidney. Differentiation. 2011; 81:81-91.

43. Tufro A, Teichman J, Woda C, Villegas G. Semaphorin3a inhibits ureteric bud branching morphogenesis. Mech Dev. 2008; 125:558-68.

44. Huang SM, Chen TS, Chiu CM, Chang LK, Liao KF, Tan HM, Yeh WL, Chang GR, Wang MY, Lu DY. GDNF increases cell motility in human colon cancer through VEGF-VEGFR1 interaction. Endocr Relat Cancer. 2013; 21:73-84.

45. Tufro A, Teichman J, Banu N, Villegas G. Crosstalk between VEGF-A/VEGFR2 and GDNF/RET signaling pathways. Biochem Biophys Res Commun. 2007; 358:410-16.

46. Tansey MG, Baloh RH, Milbrandt J, Johnson EM Jr. GFRalpha-mediated localization of RET to lipid rafts is required for effective downstream signaling, differentiation, and neuronal survival. Neuron. 2000; 25:611-23.

47. Pierchala BA, Milbrandt J, Johnson EM Jr. Glial cell linederived neurotrophic factor-dependent recruitment of Ret into lipid rafts enhances signaling by partitioning Ret from proteasome-dependent degradation. J Neurosci. 2006; 26:2777-87.

48. Osada H, Tokunaga T, Nishi M, Hatanaka H, Abe Y, Tsugu A, Kijima H, Yamazaki H, Ueyama Y, Nakamura M. Overexpression of the neuropilin 1 (NRP1) gene correlated with poor prognosis in human glioma. Anticancer Res. 2004; 24:547-52.

49. Nito C, Kamada H, Endo H, Narasimhan P, Lee YS, Chan $\mathrm{PH}$. Involvement of mitogen-activated protein kinase pathways in expression of the water channel protein aquaporin-4 after ischemia in rat cortical astrocytes. J Neurotrauma. 2012; 29:2404-12.

50. Mi H, Muruganujan A, Casagrande JT, Thomas PD. Large-scale gene function analysis with the PANTHER classification system. Nat Protoc. 2013; 8:1551-66.

51. Rhodes DR, Yu J, Shanker K, Deshpande N, Varambally R, Ghosh D, Barrette T, Pandey A, Chinnaiyan AM. ONCOMINE: a cancer microarray database and integrated data-mining platform. Neoplasia. 2004; 6:1-6.

52. Rhodes DR, Kalyana-Sundaram S, Mahavisno V, Varambally R, Yu J, Briggs BB, Barrette TR, Anstet MJ, Kincead-Beal C, Kulkarni P, Varambally S, Ghosh D, Chinnaiyan AM. Oncomine 3.0: genes, pathways, and networks in a collection of 18,000 cancer gene expression profiles. Neoplasia. 2007; 9:166-80.

53. Goodman KM, Kjær S, Beuron F, Knowles PP, Nawrotek A, Burns EM, Purkiss AG, George R, Santoro M, Morris EP, 
McDonald NQ. RET recognition of GDNF-GFR $\alpha 1$ ligand by a composite binding site promotes membrane-proximal self-association. Cell Reports. 2014; 8:1894-904.

54. Vander Kooi CW, Jusino MA, Perman B, Neau DB, Bellamy HD, Leahy DJ. Structural basis for ligand and heparin binding to neuropilin B domains. Proc Natl Acad Sci USA. 2007; 104:6152-57.

55. Greenidge PA, Kramer C, Mozziconacci JC, Wolf RM. MM/GBSA binding energy prediction on the PDBbind data set: successes, failures, and directions for further improvement. J Chem Inf Model. 2013; 53:201-09.

56. Pierce BG, Wiehe K, Hwang H, Kim BH, Vreven T, Weng Z. ZDOCK server: interactive docking prediction of protein-protein complexes and symmetric multimers. Bioinformatics. 2014; 30:1771-73.
57. Shin DH, Kim OH, Jun HS, Kang MK. Inhibitory effect of capsaicin on B16-F10 melanoma cell migration via the phosphatidylinositol 3-kinase/Akt/Rac1 signal pathway. Exp Mol Med. 2008; 40:486-94.

58. Gao J, Aksoy BA, Dogrusoz U, Dresdner G, Gross B, Sumer SO, Sun Y, Jacobsen A, Sinha R, Larsson E, Cerami E, Sander C, Schultz N. Integrative analysis of complex cancer genomics and clinical profiles using the cBioPortal. Sci Signal. 2013; 6:pl1.

59. Cerami E, Gao J, Dogrusoz U, Gross BE, Sumer SO, Aksoy BA, Jacobsen A, Byrne CJ, Heuer ML, Larsson E, Antipin Y, Reva B, Goldberg AP, et al. The cBio cancer genomics portal: an open platform for exploring multidimensional cancer genomics data. Cancer Discov. 2012; 2:401-04. 